INTER NATIONAL MONETARY FUND
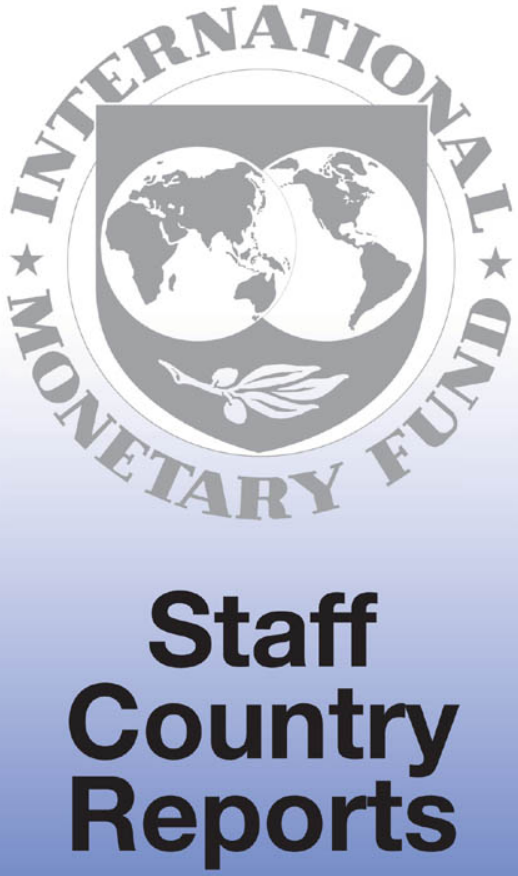
(C)1999 International Monetary Fund

November 1999

IMF Staff Country Report No. 99/129

\section{Germany: Staff Report for the 1999 Article IV Consultation}

This report was prepared by a staff team of the International Monetary Fund following discussions with the officials of Germany on economic developments and policies. The report was then considered by the IMF's Executive Board in the context of the IMF's periodic consultation with Germany, as required under Article IV of the IMF Articles of Agreement. The views expressed in the staff report itself are those of the staff team and do not necessarily reflect the views of the Executive Board of the IMF or of the authorities of Germany; a supplementary statement by IMF staff may also be included. The views of the Executive Board as expressed in the discussion of the Article IV consultation report and as summarized in a Public Information Notice (PIN) are also included. In addition, a statement by the member country authorities may be appended. Further background documentation prepared by IMF staff for the consultation may be published separately at a later date. The policy of publication of Article IV staff reports allows for the deletion of market sensitive information.

This Article IV staff report is published-both in hard copy and on the IMF's website (http://www.imf.org)-as part of a pilot project. To assist the IMF in evaluating the pilot project for release of Article IV staff reports, reader comments on the staff report are invited prior to October 5, 2000, and may be sent by e-mail to Pilotproject@imf.org.

\footnotetext{
Copies of this report are available to the public from

International Monetary Fund • Publication Services

70019 th Street, N.W. - Washington, D.C. 20431

Telephone: (202) 623-7430 - Telefax: (202) 623-7201

Telex (RCA): 248331 IMF UR

E-mail: publications@imf.org

Internet: http://www.imf.org

Price: $\$ 15.00$ a copy
}

\section{International Monetary Fund \\ Washington, D.C.}


INTERNATIONAL MONETARY FUND

\section{GERMANY}

\section{Staff Report for the 1999 Article IV Consultation}

Prepared by the Staff Representatives for the

1999 Consultation with Germany

Approved by Michael Deppler and Leslie Lipschitz

September 30, 1999

\section{Contents}

I. Introduction, Summary, and Key Issues 3

II. Economic Background

A. A Fifty-Year Perspective

$\frac{5}{5}$

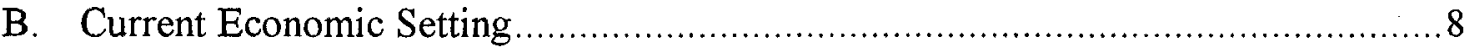

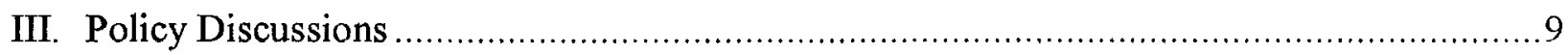

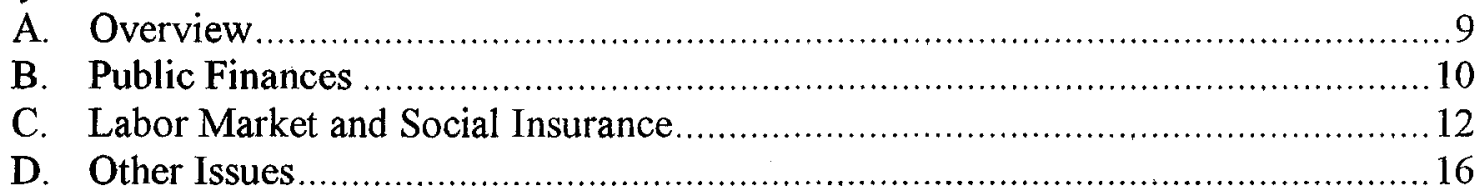

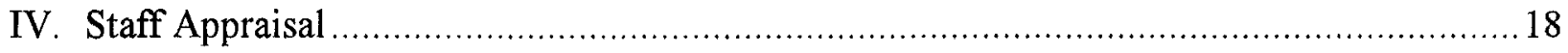

Text Boxes

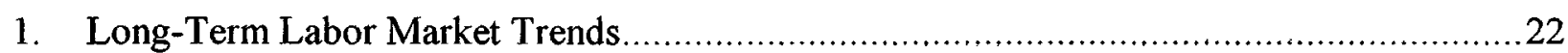

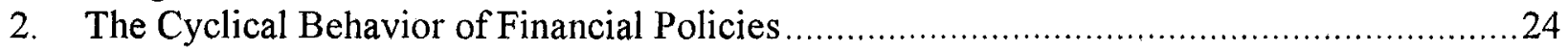

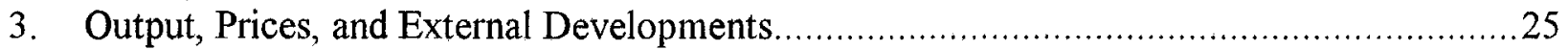

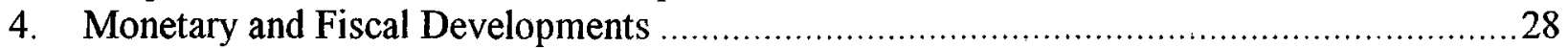

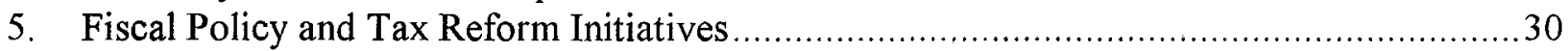

6. Labor Market Policies in Selected Continental European Countries ............................31

Text Box Tables

1. Medium-Term Projections of General Government Finances, 1994-2004

Figures

1. Real Output per Employee

2. Real GDP Growth.....

3. Unemployment Rates. 
Text Box Figures

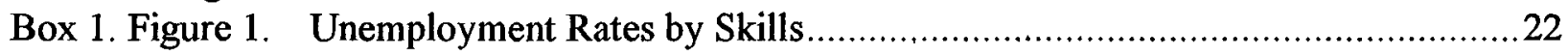

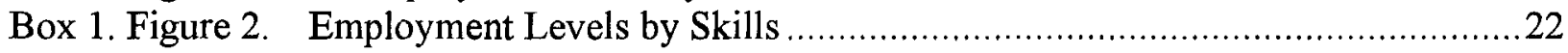

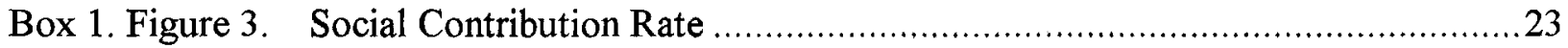

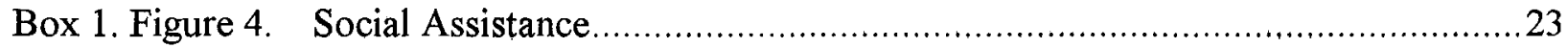

Box 1. Figure 5. $\quad$ Aggregate Wage Share and Unemployment Rate ...............................23

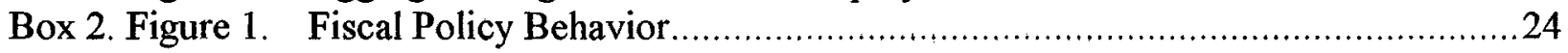

Box 2. Figure 2. Monetary Policy Behavior ...................................................................24

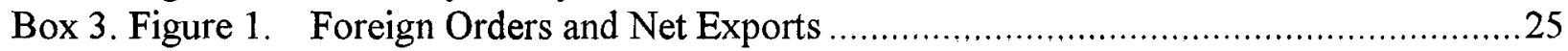

Box 3. Figure 2. Business and Consumer Confidence ….................................................25

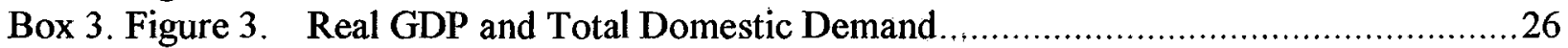

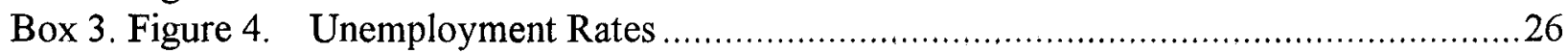

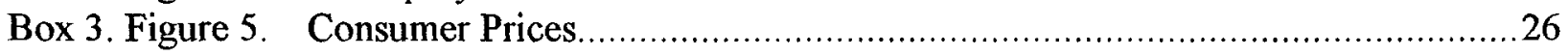

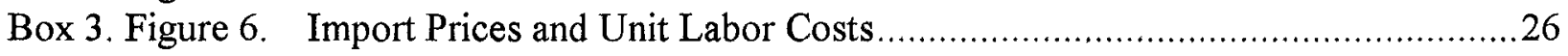

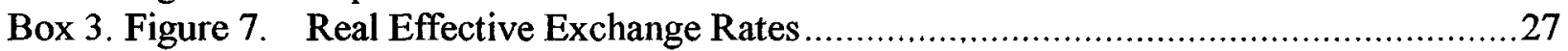

Box 3. Figure 8. Bilateral Real Exchange Rates ......................................................27

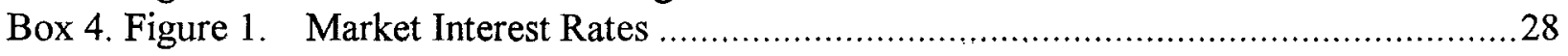

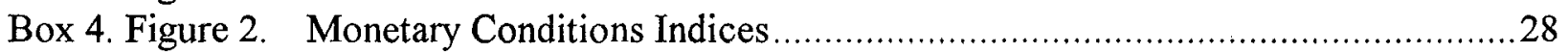

Appendices

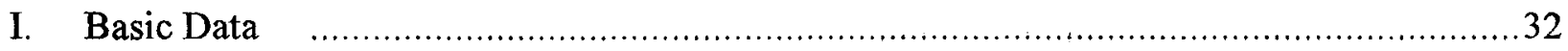

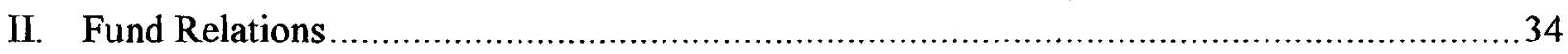

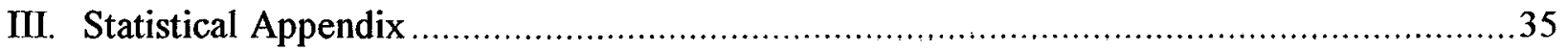




\section{INTRODUCTION, SUMMARY, AND KEY ISSUES ${ }^{1}$}

1. In its report for last year's consultation (SM/98/203, 8/11/98) the staff focused its analysis on Germany's labor market performance, found to be lagging both in absolute terms and vis-à-vis its prospective EMU partners. The basic conclusions were that this market had become asymmetrically sensitive to shocks, as demonstrated most clearly in the years following unification, and that labor market difficulties had adverse implications for overall economic performance. The report noted that while short-term economic prospects appeared reasonably favorable, this could not be allowed to mask the deep-seated structural problems that lay at the root of the labor market malaise and needed to be at the forefront of the agenda of the new government to be formed following elections in September 1998. At the conclusion of the consultation (on September 2, 1998), Directors endorsed this analysis and the associated call for comprehensive reforms focused on increasing wage dispersion, lowering nonwage labor costs, and restructuring income tax and social benefits. With inflationary pressures absent and external downside risks increasing, Directors considered the Bundesbank's monetary stance appropriate. They also emphasized the importance of allowing automatic fiscal stabilizers to operate fully once a sustainable fiscal position was achieved and urged the authorities to use the prospective cyclical upswing to undertake durable consolidation.

2. The period since the last consultation has been a turbulent one on both the economic and the political fronts. The upswing in prospect a year ago faded quickly as the emerging market crisis exerted a heavy toll on German exports, and growth came to a halt in late 1998. Activity remained sluggish in the first half of 1999 as stock adjustments worked their way

\footnotetext{
${ }^{1}$ The consultation discussions were held during June 23-July 5, 1999. Meetings were held with State Secretaries Koch-Weser and Zitzelsberger in the Ministry of Finance, thenBundesbank President Tietmeyer, President-designate Welteke, other senior officials of the Chancellery, the Ministries of Finance, Economy, and Labor, the Bundesbank, the Federal Banking Supervision Office, financial institutions, research institutes, the political opposition, and the social partners. Messrs. Esdar (Executive Director) or Donecker (Alternate Executive Director) attended most meetings. The staff team consisted of Messrs. Deppler, Fetherston, Jaeger, Ms. Kodres and Ms. Kollau (all EU1), and Mr. Prasad (RES). Germany has decided to participate in the pilot project for the voluntary release of Article IV staff reports.

Germany has traditionally published timely and high-quality economic statistics and provides data that are adequate for Fund surveillance. However, there is room for improvement in the quality and consistency of the statistics, in particular in the labor market area, and a number of temporary gaps have arisen in connection with the adoption this year of new European national accounting standards (Appendix III). Germany has subscribed to the Fund's Special Data Dissemination Standard. Germany is an Article VIII member and, apart from security restrictions noted in Appendix II, maintains an exchange system free of restrictions.
} 
through the system, but the outlook now appears more favorable. On the political front, the new SPD/Green coalition government formed following the September 1998 elections declared reducing unemployment its number one priority. However, its initial months in office were marked by controversies and uncertainties as to its strategy for achieving that objective-uncertainties which cast their shadow over the tenor of policies in Europe more generally, and over Germany's role in the smooth launch of the euro. Also, recent state election losses have cost the coalition its majority in the upper house (Bundesrat), complicating its legislative task.

3. Recent months have seen the government bring greater clarity to its policy intentions in key areas. As detailed below, there is much to welcome in its recent initiatives, notably regarding fiscal policy, and tax and pension reforms. Nonetheless, in the key area of labor policies, prospects are not good: the initial steps taken by the new government were retrograde from the standpoint of improving the overall functioning of the labor market, and the staff's discussions on the need for more differentiated labor cost structures was met, both inside and outside the government, with at best cautious reserve. Also, recent organizational changes (involving the transfer of strategic policy planning between ministries) have slowed the formation of a structural agenda. Overall, there is a considerable risk either of policy inertia or of policies from a traditional German "corporatist" mould that would not do the job.

4. While such policies were associated in the past with an economic record that was the envy of many, they would in the staff's judgement foretell less than first-class output and employment growth over the medium term. The economy would increasingly be exposed to a renewed bout of labor shedding down the road in the face of cyclical shocks or more exogenous ones (such as a result of EU enlargement) that increase competitive pressures on lower-paid labor. Continued below-par German macroeconomic performance resulting from persistent labor market problems would then have adverse implications for Germany's euro area partners and the global economy.

5. With staff conclusions little changed from those of a year ago, this year's report emphasizes the historical roots of Germany's policy responses. This analysis serves to explain both the controversies and the policy decisions and non-decisions of the past year, and why those traditional policy responses need to be adapted if Germany's economic performance is to regain its former luster, to the benefit of all. This framework also provides the context for the report's premise, that-notwithstanding widespread misgivings on the part of many interlocutors in Germany that the staff is advocating "Anglo-Saxon" remedieseffective solutions to Germany's labor market problems must be tailored so as to be acceptable within the German socio-economic context. This is so not only because each of the key players has in effect a right of veto but also because several of Germany's neighbors have achieved a measure of success with similar problems on the basis of their own homegrown strategies. 


\section{ECONOMIC BACKGROUND}

\section{A. A Fifty-Year Perspective ${ }^{2}$}

6. The institutions of Germany's social market economy, established half a century ago in reaction to pre-war developments, feature a clear division of responsibilities among the key economic players and clear rules of the game. There are five key pillars of the system, designed to combine social solidarity and protection with adequate market incentives:

-Monetary policy, entrusted to a strong and independent central bank, the Bundesbank, bound to an objective of price stability (and with the January 1999 advent of the euro, now devolved to the European Central Bank (ECB)).

-A clear separation of the public and private sectors in wage setting, with constitutionallymandated autonomous collective bargaining between trade unions and employers' associations, the results of which are often binding (partly through administrative extension) on the rest of the economy. Traditionally, unions have given a very high weight to "solidarity" objectives, i.e., similar improvements in wages and nonwage conditions and benefits across workers at different skill levels, sectors, regions, and firms. This has led to a wage structure characterized by narrow differentials that have remained remarkably stable over time (Selected Issues, Chapter III). Unions have also viewed wage push as a means to spur firms to increase productivity, while at the same time being mindful to safeguard sufficient profits to sustain investment.

- A large-scale social insurance system (covering the risks of old age, health, and shortterm unemployment) managed by the public sector on the "parity" principle, i.e., a unified social contribution rate levied proportionally across most of the wage distribution and with individual social insurance benefits linked tightly to contributions.

-A generous social safety net for the long-term unemployed (unemployment assistance) and persons with low incomes (social assistance) based on the principle of a minimum income guarantee (tied to average wage growth) that in effect established a relatively high wage floor.

-And fiscal policy, left with the task of financing these and other social spending obligations within a framework of overall financial discipline, was allotted to an intricate power sharing system between the federal and Länder governments. The guiding principles were constitutional "golden rule" constraints at the various levels (limiting credit financing to investment spending) that encouraged a focus on nominal deficit targets.

${ }^{2}$ The summary account presented here is necessarily stylized. A fuller analysis is provided in Chapter I of the accompanying Selected Issues Paper. 
7. These institutional arrangements worked exceptionally well in the auspicious economic environment of the Wirtschaftswunder era of the third quarter of the century, but less so as the phase of catch-up growth waned. For much of the post-war period, the German economic and social system was envied by much of the world for a wide range of achievements - both in its macroeconomic dimensions of rapid growth, financial stability, and extremely low unemployment, and in other respects, notably living standards, social equity, and job-related youth training. However, in more recent decades Germany's performance lost its luster, and tensions between the "social" and "market" elements of the economy came increasingly to the fore. While financial stability was maintained, growth slowed (as in many countries) as the catch-up phase ended (Figures 1 and 2), and labor market performance slipped from well-above to well-below average (Figure 3). Nor is the labor market slippage simply vis-à-vis Anglo-Saxon countries or attributable to eastern Germany, as is often alleged. Over the past decade, it is also evident vis-à-vis generally likeminded (as regards socio-economic policies) neighbors, e.g., Denmark, the Netherlands and, more recently, France (see below); and employment declined as much in western as in eastern Germany from 1992 to 1998 . The labor market deterioration was concentrated on three ratchet-like episodes prompted by shocks and overwhelmingly concentrated among the lower-skilled (Box 1, and Selected Issues, Chapter I).

Figure 1: Real Output per Employee 1/

Figure 2: Real GDP Growth 1/

(Thousands of U.S. dollars at

1995 prices; logarithmic scale)
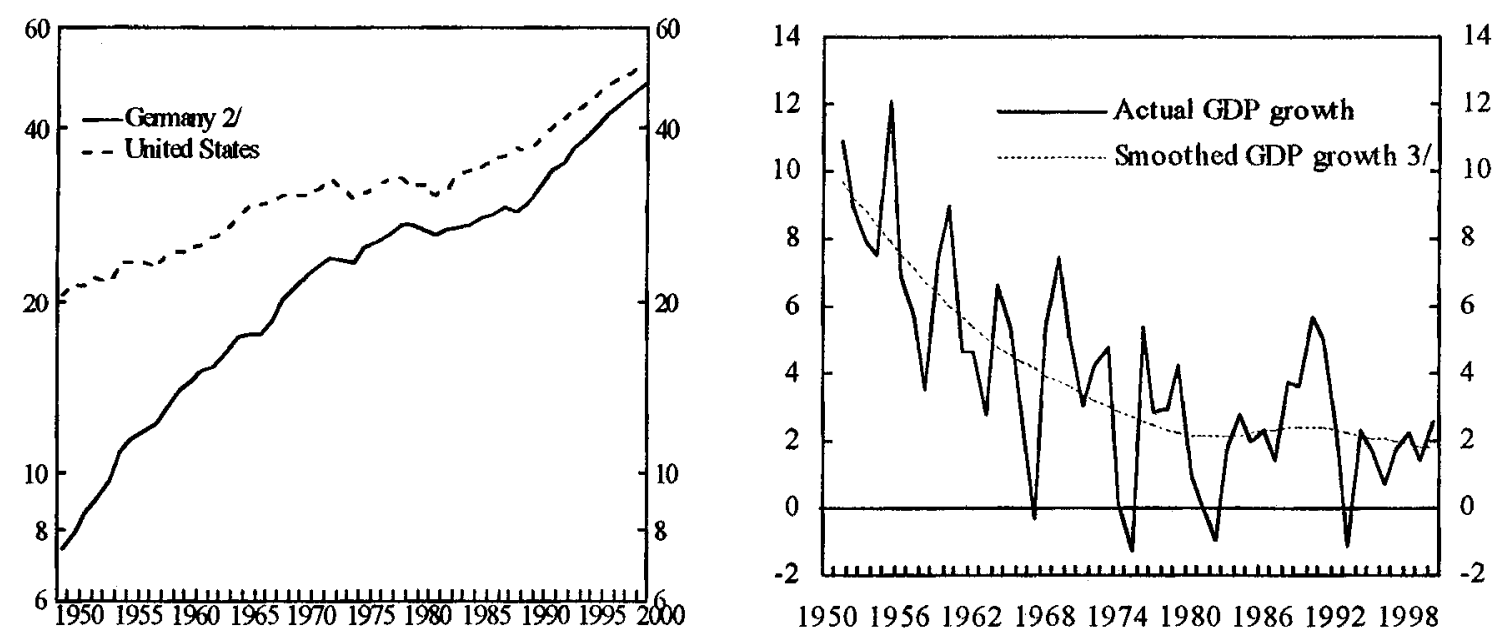

Sources: World Economic Outlook database; Deutsche Bundesbank; Penn World Tables 5.6; and staff estimates and projections.

1/ Data for 1999-2000 are staff projections.

2/ Data for 1991-2000 refer to united Germany.

3/ Hodrick-Prescott filter estimates. 
Figure 3: Unemployment Rates

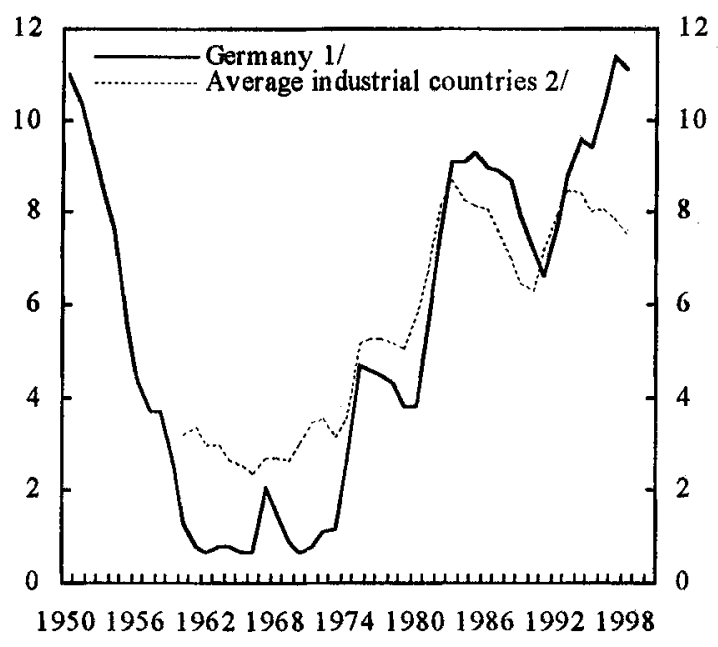

Sources: Deutsche Bundesbank, German Council of Economic Advisors; and staff calculations.

1/ Data for registered unemployment 1991-1998 refer to united Germany.

$2 /$ Weighted average.

8. The basic dynamics of such episodes are roughly as follows. Starting from approximate macro-equilibrium, initially moderate pay rises give way as the recovery proceeds to increasingly aggressive wage demands as profits rebound and labor demand increasingly shifts in favor of higher-skilled/better-paid workers at the expense of lowerskilled/lower paid workers (Box 1). While this pushes the former's labor costs to the acceptable frontier, the principles of solidarity in wage bargaining and parity in social insurance contributions push up labor costs for the less skilled further and further beyond their productivity. While this can for a while be covered by price increases, eventually, particularly when faced with a downturn, enterprises shed massive amounts of low-skilled labor. However, with the social safety net raising the effective wage floor in line with average wages, the low-skilled are unable to price themselves back into employment. The resulting rise in structural unemployment forces higher social contribution rates (to finance the rise in unemployment benefits), exacerbating the problem of cost competitiveness at the low end, and, through both the resulting narrowing of the tax base and higher spending on unemployment and social assistance, adding to general fiscal pressures and triggering policies designed to observe the constitutionally mandated golden rule requirements (Box 2). Along the way, monetary policy becomes focused on wage developments and turns restrictive at an early stage. The cyclical strains on the economy thus become quite marked. Eventually, once the process of labor shakeout has run its course, the process of perverse responses goes into abeyance until the next adverse shock. As documented in last year's report, the last of these shocks - unification-was especially perverse, as it prompted a cyclical de-synchronization with Germany's ERM partners and was exacerbated by both the 
decision to transpose western German institutions (including labor cost structures) into eastern Germany and by the policy commitments associated with the move toward EMU. ${ }^{3}$

9. In practice, market pressures have led to modifications and adaptations that have tempered the adverse effects. Businesses in high wage sectors (mainly manufacturing) have increasingly outsourced activities to lower-wage sectors-a phenomenon that helps explain the contrasting trends in observed competitiveness of manufacturing and the whole economy (see Box 3, Figure 7). Overall wage demands, while subject to flare-ups, have often been moderate, notably during much of the $1990 \mathrm{~s}$. Moreover, wage bargaining became more flexible at the local level than implied by national agreements, although the proportion of workers not covered by tariff agreements remains only a third of the total. The most prominent adaptation has been the increasing recourse to the relatively loosely regulated category of so-called "DM 630 jobs" (see below). However, the Government has taken steps to close this and other escape valves.

\section{B. Current Economic Setting}

10. By 1998, the latest labor shakeout episode had been completed and the economy looked poised for a cyclical upswing. ${ }^{4}$ Instead, the upswing was aborted by the emerging market crisis which hit German exports particularly hard and stopped growth in its tracks in late 1998 (Box 3). The resulting knock to business confidence was exacerbated, moreover, by uncertainty about the new government's policy direction.

\section{Looking forward, an improving external environment, easier monetary} conditions, and greater policy clarity should now permit a moderate recovery to unfold in the near term. Monetary conditions in the new institutional context of EMU have eased considerably since late 1998, reflecting both policy actions and the depreciation of the euro (Box 4). Fiscal policy by conventional measures is contractionary for the near term, but the authorities' recent clarification of its medium-term budgetary and tax reform strategy should, with firm implementation, alleviate uncertainties and underpin increased investment. Overall, there is broad agreement (among the authorities, staff, and most private analysts) that output should pick up to an above-potential rate in the second half of 1999, with GDP growth on the order of $1 \frac{1}{2}$ percent in 1999 and $2 \frac{1}{2}$ percent in 2000 . The risks to this outlook, earlier tilted to the downside, appear now broadly balanced. Recent short-term manufacturing indicators

\footnotetext{
${ }^{3}$ Reflecting these stresses, including the sharp appreciation in Germany's real effective exchange rate associated with the transfer of resources to the east following unification, Germany's growth and labor market performance in recent years has lagged behind that of France. See also the Staff Report for the 1999 Article IV consultation with France, Appendix II.

${ }^{4}$ The recent adoption of new national accounting standards has led to temporary gaps and increased uncertainties in the interpretation of cyclical indicators.
} 
have been stronger than expected, suggesting scope for more rapid pickup in activity; at the same time a hard landing in the United States is a source of downside risk.

\section{Prospects beyond the reasonably favorable short term nevertheless remain} clouded by structural problems and the risks of a further round of adverse labor market dynamics. Although recent wage settlements (of about 4 percent) appear unlikely to trigger another round of large-scale labor shedding in the near future, further rounds of across-the-board wage increases would sow the seeds for another round of labor shedding in the next cyclical downturn and thus undermine macroeconomic prospects.

\section{Policy Discussions}

\section{A. Overview}

13. The consultation discussions underscored a clear sense among policy makers of the need to set Germany on a track of stronger performance. Their strategy featured a decisive reassertion of traditional approaches to policies, notably in the public finances, but also in strengthening market incentives. Less benignly, some of the same instinct to restore order was apparent with respect to labor market policies, where the traditional tensions between the social and the market aspirations of Germany's economic establishment have led to tighter regulation. Nonetheless, the prevailing thrust was seen, at least by some, as setting the stage for a more wide-ranging structural agenda that would address institutional reforms, but this agenda was yet to be defined and fleshed out.

14. With the shift in monetary policy responsibilities to the ECB and the new arrangements for Fund surveillance of euro area policies, the policy discussions focused on fiscal and structural issues. As regards monetary conditions (Box 4), the staff commented that the ECB's April policy easing was helpful for Germany given its relative cyclical position (a prospective output gap of about $2 \frac{1}{2}$ percent in 2000 , some $3 / 4$ percentage point larger than in the rest of the euro area). ${ }^{5}$ The authorities, including officials of the Bundesbank, considered that inflation for the time being was under control and that monetary policy was appropriately supportive of German activity. The strengthened competitiveness associated with the depreciation of the euro had also been helpful in moderating the negative impact of the export shock. The staff observed in this connection that, with the euro viewed as currently undervalued relative to fundamentals, competitiveness could come under pressure from the exchange rate side over the medium-term-reinforcing the case for a focused assault on structural problems, especially in the labor market. Given the nature of those problems, the traditional response of calls for across-the-board wage moderation would not be sufficient (see below).

\footnotetext{
${ }^{5}$ The staff's discussions with the ECB on euro area monetary and exchange rate policy issues were reported in SM/99/212, 8/23/99.
} 


\section{B. Public Finances}

\section{In presenting the June $\mathbf{1 9 9 9}$ fiscal package—covering budget plans for $\mathbf{2 0 0 0}$ and} the medium term, supporting expenditure measures, and business tax reforms-the authorities emphasized the need to restore equilibrium to the public finances and in particular to arrest the accumulation of government debt. In that vein, the package reflects the traditional focus on nominal deficit targets aiming for balance over the medium term. Moreover, much of the adjustment is front loaded, in order in the first instance to observe the constitutional Golden Rule requirement that limits current federal spending to projected current receipts (including privatization)-a significant hurdle in 2000 because of a fall off of some DM 18 billion in privatization revenues. At the level of general government, staff estimates suggest that the deficit (excluding privatization) might fall from almost 2 percent of GDP in 1999 to just over 1 percent in 2000, and converge to approximate balance over the medium term (tabulation). On present growth projections, the associated fiscal impulses are fairly small, the largest being a negative 0.4 percent of GDP in 2000 (Box 4, Table 1). ${ }^{6}$

\begin{tabular}{lccccc}
\multicolumn{7}{c}{ Germany: General Government Finances } \\
(In percent of GDP) \\
\hline Revenue & 1999 & 2000 & 2001 & 2002 & 2003 \\
\hline Expenditure & 47.1 & 46.9 & 46.5 & 46.1 & 46.2 \\
Balance & 49.0 & 48.0 & 47.3 & 46.6 & 46.4 \\
& -1.9 & -1.1 & -0.8 & -0.5 & -0.2 \\
\hline
\end{tabular}

Source: Box 4, Table 1 .

16. The package's consolidation effect is entirely focused on the expenditure side, thereby making room for the authorities' planned tax reforms and an associated decline in the revenue/GDP ratio ( 1 percentage point over the medium term). The expenditure/GDP ratio is projected to fall by $2 \frac{1}{2}$ percentage points. Moreover, the cuts represent a move away from across-the-board spending reductions ("lawnmower approach") which have been the mainstay of past consolidation exercises, to a more targeted approach geared to reducing subsidies, the public wage bill, and social transfers. The most controversial of these measures has been the proposal to index pensions to prices rather than net wages for the next two years, a measure that lowers the replacement ratio for both existing and all future new pensioners from about 70 to 67 percent. With the lower replacement ratio coming into effect at an early stage (and much sooner than under the previous government's plan for gradual

\footnotetext{
${ }^{6}$ The exact path of the structural fiscal position over time in the staff's analysis reflects the timing of future income tax reform packages: the business income tax reform in 2001, and the household income tax reform in 2002. The authorities' fiscal policy initiatives are analyzed in Chapter II of the accompanying Selected Issues paper.
} 
phasing in of a "demographic factor" in the pension benefit formula), this step would significantly reduce implicit public pension liabilities. ${ }^{7}$

17. The staff strongly welcomed the package, both for the targeted nature of the cuts, which is fully in line with past Fund advice, and for the renewed impetus toward fiscal consolidation that it implied given the relative lack of ambition on this front in the 1999 budget. The staff noted in this respect that international experience suggests that expenditure-based consolidations of this type (i.e., focused on current outlays) tend to be the most durable and, hence, confidence-inducing.

18. There was less agreement on how the nominal deficit targets set out in the plan should be interpreted. Given the economic outlook and the prospective development in the fiscal position, the risks of approaching the 3 percent deficit ceiling of the Stability and Growth Pact (SGP) seemed slight. The staff thus pressed the view that the achievement of the nominal deficit targets should be viewed as contingent on growth evolving in line with budgetary assumptions, with the automatic stabilizers being permitted to operate in case of deviations. This had become particularly important in the context of EMU, so as to ensure that national fiscal policies do not reinforce cyclical developments and can provide support in case of a weakening of activity. The authorities agreed that this conception underlay the SGP, but only once the norms of the pact had been achieved, which was still not the case. They also pointed to the difficulties of allowing the operation of stabilizers at lower government levels in Germany's decentralized system of government finances and, more fundamentally, to the benefits for credibility and confidence of clear commitment to, and achievement of, nominal deficit goals.

19. The authorities emphasized their continued commitment to tax reforms. The existing system features large spreads between top marginal and effective average income tax rates on both labor and capital, and narrow tax bases, reflecting a wide range of exemptions that expanded temporarily in the wake of unification as the tax system was used to promote investment in the new Länder. ${ }^{8}$ Their first step, passed into law in March, featured cuts in personal income tax rates, medium-term tax relief of about $1 / 2$ percent of GDP for private households, and base broadening for businesses and households (see Box 5 and Selected Issues, Chapter II). More recently, the June package proposed a comprehensive reform of business income taxes, featuring a major reduction of overall tax rates on retained profits (by about 15 percentage points-see Box 5) and a shift away from full imputation. In this

\footnotetext{
${ }^{7}$ Preliminary staff calculations suggest that this measure could reduce Germany's estimated implicit pension liability of some 110 percent of GDP by about one quarter.

${ }^{8}$ In particular, the special depreciation allowance of 50 percent for fixed investment projects in eastern Germany - which was granted in addition to any normal depreciation or investment allowances-was phased out in 1996. Corporate and assessed income tax collections have recovered markedly since 1996.
} 
context, the authorities explained that, against a background of sharp increases in crossborder capital flows among EMU countries, market pressures for reform of the corporate tax had become impossible to resist for two reasons: first, Germany's corporate tax rates were high by European standards; and second, the full imputation system, under which recipients of dividends received full credit against their tax liability for corporate tax paid on distributed profits, was becoming increasingly unworkable as most other countries did not operate such a system. They recognized that their proposals would tilt the playing field toward retention of profits for financing investment. ${ }^{9}$ This was not viewed with concern, and indeed could serve to boost investment; moreover, most other countries had similarly uneven playing fields. The staff commented that this tilt toward retention could bottle up capital in companies, with adverse implications for the efficient allocation of capital, and pressed for a more neutral system. The authorities also recognized that the widening of the spread between top rates on retained earnings and personal incomes could lead to pressures for further change.

\section{Labor Market and Social Insurance ${ }^{10}$}

\section{The authorities emphasized that strengthening labor market performance was} the priority policy objective. In this regard, the policies of fiscal consolidation, tax reform, and respect for the division of labor between fiscal and monetary policy were all policies designed to restore confidence, get the economy back on track, and reduce unemployment. While this was a different approach from that of some in Germany who pressed for a direct strengthening of demand, it was an approach that had worked in the past-most notably in conjunction with the recovery in the 1980s-and would work again. By the same token, a large share of unemployment was admittedly structural so that additional steps would need to be taken. To this end, the government had established a multipartite forum (the Alliance for Jobs, Education, and Competitiveness) to generate ideas and foster consensus. The Alliance's work was, however, still at a relatively early stage, with differences between employers and unions on the agenda still being worked out; and within the government there was not as yet a consensus on the necessary scope of reforms. In the meantime, the authorities continued to implement a range of active labor market policies targeted at the unemployed, including a new initiative aimed at providing 100,000 youth with employment and training opportunities. These policies, together with those of the previous government, largely account for the bulk of the decline in unemployment since early 1998.

\footnotetext{
${ }^{9}$ Under the proposed reform, retained earnings would be taxed at a total rate (federal and local) of about 38 percent, compared with over 50 percent for distributed profits.

${ }^{10}$ Additional background analysis of the labor market issues discussed in this section is presented in Chapters III and IV of the accompanying Selected Issues paper. Chapter III documents Germany's narrow wage differentials and stable wage structure that have resulted from current bargaining structures; Chapter IV analyzes the role of tax /transfer modifications in supplementing institutional labor market reform.
} 
21. The authorities recognized the importance of alleviating the heavy burden of nonwage labor costs inherited from the past, and had taken a series of steps to make room for lower social contribution rates. First, measures were being taken to contain the burden of social benefit spending, specifically by indexing pension benefits to prices rather than net wages for the next two years. Second, the government is committed to a green tax swap that uses increased ecotaxes (on mineral oils and electricity, levied mainly on households) to finance an across-the-board cut in social contributions. The first step of the ecotax reform went into effect in April, and a second was announced in the June package. The authorities saw such swaps as helpful in arresting the hitherto inexorable increase in social contributions, but acknowledged that claims of "double dividend" benefits-an improved environment and a reduced excess burden of the tax system-may be exaggerated as consumption-based ecotaxes ultimately fall mainly on labor. To stabilize healthcare contribution rates, health spending will be subject to nominal ceilings, with increasing demand to be met through efficiency gains. ${ }^{11}$ These initiatives to reduce or at least contain social contribution rates are complemented by calls for overall wage moderation, while maintaining the traditional hands-off position of government with respect to wage negotiations.

22. The authorities also had developed preliminary proposals for systemic pension reform, which would represent a step toward establishing a multi-pillar pension system. The present large-scale public pension pillar would be supplemented by a mandatory private pension pillar to alleviate future burdens on the state scheme and the associated need for further increases in social contributions (in particular in view of projected population aging from 2010 onward). The proposed private pension pillar entailed mandatory employee contributions - increasing from 0.5 percent of gross earnings beginning in 2003 to a total of 2.5 percent of gross earnings by 2007 - to a private pension plan, possibly combined with tax incentives. The mandatory aspect had, however, proved controversial given the impact on the cash flow of lower-paid workers and further consultations were planned within the context of the Alliance for Jobs. The government remains, however, committed to strengthening private pension provision, and plans to present its final proposals by the end of this year.

\section{The authorities' across-the-board actions aimed at strengthening incentives in} the labor market have been complemented by other, less benign ones. The most prominent of these involves a marked tightening of the arrangements for DM 630 jobs. These part-time jobs, defined by ceilings on work time and earnings, had been exempt from social contributions and subject to a low flat rate of tax, and their number had expanded rapidly. ${ }^{12}$

\footnotetext{
${ }^{11}$ Policies on health costs are analyzed in detail in the 1999 OECD Economic Survey of Germany.

12 These are jobs defined by work time of less than 15 hours per week and earnings below a threshold, currently DM 630 or about one-sixth of the average monthly gross wage. Prior to April 1999, jobs were exempt from social contributions and subject to a flat rate income tax
} 
The authorities explained that inequities such as those between those holding DM 630 jobs as a second job and those working overtime at a regular job needed to be addressed. The previous flat income tax had therefore been abolished and DM 630 jobs were now subject to social contributions (at a reduced rate), a shift which, while it kept taxes on an individual's first DM 630 job unchanged, made it possible for the tax authorities to identify recipients of income from DM 630 jobs and collect income tax at the appropriate marginal rates. While not unreasonable from the standpoint of tax administration and equity, the new policies nonetheless imply a steep rise in the cost of labor at the low end, a steep worsening of the incentives facing the low paid to work-the 631st DM increases social contributions by DM 130 - and, more broadly, a tightening of regulation on the one dynamic niche of the labor market. In addition, the incoming coalition rolled back in late 1998 two labor market initiatives of the previous government (which had relaxed dismissal procedures and curbed sick pay).

24. These aspects aside, the staff viewed generalized policies to reduce labor taxes as clearly appropriate and helpful, but, taken as whole, unlikely to achieve a lasting and sustained reduction in structural unemployment or to foreclose new episodes of labor shakeout in response to future shocks. Those policies would not break the nexus between wage solidarity, parity, and the minimum income guarantee that were at the root of many of the present difficulties, including the high level of social insurance contributions. In the staff's view, what was needed was less emphasis on generalized policies, and more focus on policies that addressed the evident problems at the low end of the labor market, to the lasting benefit of employment and the longer-term growth of the economy.

\section{The challenge was to establish collective bargaining institutions that would} match labor cost and productivity of the lower skilled, to move to a multipillar social insurance system that would avoid charging very high social contributions at the lower end of the labor market, and to strengthen incentives for the lower paid. Countries elsewhere in Europe facing not dissimilar problems had managed to forge new social compacts that had engendered significant improvements in labor market performance or had long-standing labor market institutions that had been effective in containing labor market problems (Box 6). In the same vein, the Alliance for Jobs seemed to provide a promising opportunity for a new social compact in Germany. In the staff's view, this would necessitate abandoning entrenched positions-on "wage solidarity" through provision for increases in the differentiation of labor costs, with wages at the lower end increasing little if at all; on the design and size of the social insurance system wherein the government (and the social partners) accepted a more graduated or progressive structure for social contributions as well as a downsizing of the current dominating public pillar (with the more diversified social insurance systems in the Netherlands or Switzerland serving as possible benchmarks); and on

withheld at source. The number of these jobs is estimated to have risen to over 5 million (over 10 percent of the labor force) by 1997; many were held as second jobs, and instances of individuals holding multiple DM 630 jobs were also common. 
tightening eligibility for unemployment and social assistance (an approach that had been successful in Denmark).

26. As noted earlier, these views met, as was broadly the case also a year ago, with at best reserve from the staff's interlocutors. A range of concerns were expressed:

- In the view of some, the staff was advocating a pure, market-driven solution that was not tailored to Germany's situation and would lead to an inappropriate and unwanted shift in the income distribution. The staff countered by stressing the relevance to the German context of the initiatives and experiences provided by other European countries--which the authorities indicated they were studying carefully. The issue was not social objectives regarding the distribution of income, but whether those objectives together with those for growth and employment were best met via tax-and-transfer or labor market mechanisms.

- Some pointed to the absence of clear evidence in the German context that more wage and labor cost differentiation would help address these problems. However, in the staff's view there was plenty in the experiences of countries to suggest that the price mechanism was critical to addressing labor market issues and that experimentation was warranted. First, the size and the composition of labor shakeouts in Germany clearly suggested that the cost of low skilled labor was a problem. Second, youth unemployment was much lower in Germany and the Netherlands than in France, which did not have arrangements that allowed youths to be paid less. Third, the French authorities' massive and recently enlarged policies to systematically rebate social security contributions for those employed at or near the minimum wage seemed to be having a payoff in terms of employment.

- On this score, the fiscal authorities expressed concern about the fiscal implications of rebating contributions and suggested that an approach focused on enhancing labor supply incentives might be a more efficient way forward. The staff agreed that such measures were also essential. As Germany's mixed experiences with targeted wage subsidies demonstrated, ${ }^{13}$ policies needed to focus on enhancing incentives to work as well as those to hire. ${ }^{14}$ The former would require tightening eligibility requirements (and the associated strengthening of cooperation between federal and other territorial authorities) and smoothing the withdrawal of benefits as persons rejoined the labor force. By the same token, however, supply side measures alone would also not do the job. Reabsorbing the unemployed would require steps to increase the demand for their labor services. From that standpoint, a marked reduction in social contribution rates for that segment of the market could, in tandem with the recovery and more flexible wage or employment structures, help jump-start the process. This would indeed have fiscal implications that needed to be considered carefully. In particular, a scheme which could prove budgetarily

${ }^{13}$ These experiences are assessed in the latest OECD Economic Survey of Germany.

${ }^{14}$ See also Selected Issues paper, Chapter IV. 
expensive, and mortgage future progress toward lowering the overall tax and labor cost burden, should be launched only in the context of a comprehensive package that provided reasonably firm assurances about the medium term implications for employment and growth, and hence the fiscal accounts and the tax burden.

- Finally, a periodic theme in the discussions was that German institutions embodied clear assignments of responsibilities and basic principles - for instance, assignment of wage bargaining to the social partners, not the government, and the principle of parity between social contributions and benefits. The staff argued that while these traditions and institutions made sense viewed in isolation, they no longer functioned well in the aggregate. Collectively, they generated negative externalities-increases in unemployment and a weakened growth performance-that needed to be addressed. There was a real risk that the debate would become increasingly polarized, leading to narrow deals of interest mainly to higher-skilled workers (see Box 1) that would make the underlying problems worse (as with the DM 630 jobs measure). What was needed was rather a joint stock-taking of the collective nature of the problem and of the need for each of the key players to contribute to the solution in ways that might stretch traditional roles.

\section{Other Issues}

\section{In product markets, while recognizing that much remains to be done, the} authorities pointed to significant reforms underway that were already bearing fruit. Germany was well ahead of EU requirements for energy deregulation, with the April 1998 energy law opening up the electricity system for third-party access and thus increasing competition, with electricity prices in some cases falling by as much as 20 percent. Deregulation of telecommunications had been followed by even more dramatic price cuts (some telephone charges down 85 percent since 1997). Public procurement procedures had been revised in 1998 to simplify participation requirements and increase transparency of bidding. The effects of the partial 1996 liberalization of shop opening hours (which are still among the most restrictive in Europe) were under study with a view to further relaxation; this remained a contentious issue, especially with trade unions. The government remains committed to an active privatization policy: plans for 2000 include further sales of government holdings in Deutsche Telekom (currently 72 percent state-owned) and privatization of Deutsche Post. Other areas for future privatization include railways, housing, and airports. It was acknowledged, at the same time, that the burden of regulation on business remains heavy and that business start-ups face considerable barriers. ${ }^{15}$

${ }^{15}$ According to the 1998 OECD Economic Survey of Germany, firms are subject to some 80,000 regulations at the federal level alone, with additional regulations imposed by lower levels of government. 
28. The authorities viewed the financial system ${ }^{16}$ as sound. The storm in emerging markets had been weathered, but internationally active German banks still have some of the largest industrial country exposures to emerging markets. As of July 1999, German banks have over half the total exposure to Russia ( $\$ 25$ billion), the largest exposures to other Eastern European countries ( $\$ 19.5$ billion), and the second largest exposure to Brazil ( $\$ 5.1$ billion). While these exposures are a potential source of vulnerability, the authorities pointed out that provisioning for country risk has increased and many loans contain underlying governmental guarantees (especially for Russia) and that the 1998 annual accounts for all German banks showed increasing annual profits. ${ }^{17}$ Domestically, some German banks have suffered greater than expected credit losses on commercial real estate and construction lending, particularly in eastern Germany, and the potential for a deterioration of credit quality is a concern among the banking community, credit rating agencies, and the supervisors. It is difficult, however, to assess this risk because statistics providing breakdowns of regional lending are not produced and banks are not required to publicly disclose detailed information about the quality of their loan portfolio. German stock and housing markets have been subdued, with no indication of asset price bubbles.

29. The German banking industry is facing mounting competitive pressures in response partly to the advent of EMU, but also to general financial market globalization trends. The authorities agreed that Germany was still overbanked, even with the steady consolidation of the credit cooperative sector, and that German banks will need to become more efficient to compete with their counterparts both within and outside Europe. The mission inquired whether enhanced efficiency had been slowed by the limits on outside shareholder interest in the Landesbanken and Sparkassen (as publicly-owned banks) and the credit cooperatives (mutually-owned banks), and about the effects on competition and merger incentives of government guarantees which lower the cost of capital for the Landesbanken.

30. In response, the authorities viewed the Landesbanken and Sparkassen as satisfying a valid public purpose, which would not otherwise be provided in a competitive environment, giving the rationale for the continued government guarantees. They were concerned in this context at the prospect of an adverse EU ruling on the capitalization of one of the 12 Landesbanken. ${ }^{18}$ Further, the authorities believed that the efficiency of the banking sector

\footnotetext{
${ }^{16}$ Developments in Germany's financial system are analyzed in Chapter V of the accompanying Selected Issues paper.
}

17 The bulk of bank claims, including those on nonresidents, are denominated in domestic currency. As regards Russia, DM 16 billion (25 percent of German banks' loans to Russia) represent guaranteed loans from the former DDR Staatsbank.

${ }^{18}$ Subsequently the EU Competition Commission ruled against West LB (the largest of the Landesbanken) which had earlier received a public capital infusion at below-market interest rates. See Chapter V of the Selected Issues paper, Box 2, for details. 
could be enhanced without significant alteration to its present relatively fragmented form, noting this arrangement had been associated with few episodes of instability and has not required taxpayer funds since the 1930s. While these arguments have some merit, the staff noted that it was difficult to assess the efficiency with which the Landesbanken and Sparkassen were, in fact, fulfilling their public mandate. For instance, accounting information identifying regional development loans, and the degree to which this type of lending is subsidized, is not readily transparent. Further, it is clear from their annual reports, that the Landesbanken compete directly with other private commercial banks, lending to the same client base both inside and outside the states they represent.

31. The new coalition government has largely adopted the three-pronged policy approach of the previous government to fostering convergence by eastern Germany: provision of a modern transportation and communications infrastructure; a time-limited (until 2004) investment promotion program focused on the manufacturing sector; and continuation of large-scale active labor market programs, which cover some 12 percent of eastern Germany's labor force. Within the Alliance for Jobs framework, a separate working group focuses on new policy strategies for eastern Germany.

32. Concerning trade policy, the authorities acknowledged that the ultimate agreement to reform the Common Agricultural Policy in the context of Agenda 2000 fell short of the tentative measures announced previously by the EU farm ministers; this was unfortunate, but reflected the realities of a multi-faceted negotiation. Germany's ODA, currently 0.28 percent of GDP, is budgeted to decline slightly over the medium term.

33. Independent assessments of Y2K preparedness place Germany in an intermediate position among the industrial countries. The authorities expect no significant difficulties for the federal administration; while private sector readiness varies (with larger companies more advanced), the vast majority are expected to complete the necessary work on time and no major disruptions are envisaged.

\section{STAFF APPRAISAL}

34. Germany's short-term outlook is reasonably bright, thanks in part to more decisive macroeconomic policies, but enduring structural weaknesses point to less comforting medium term prospects. Unless a fresh approach is taken to improving the functioning of the labor market, prospects are for a continued less than first rate growth performance, punctuated by further bouts of labor shedding. Such a performance would be detrimental not only to Germany, but also to the European and global economies.

\section{Following an initial period of uncertainty, recent initiatives in the fiscal area} have provided clarity and direction to the government's macroeconomic policy strategy. As the unification and emerging market shocks continue to recede, and with monetary conditions supportive of activity and appropriate for Germany's current circumstances, the stage is set for a period of stronger, above-potential growth. 
36. The scale, pace and especially the composition of the government's fiscal package for 2000 and beyond are the right ones. The package reconfirms Germany's commitment to fiscal consolidation and thus also sets, in the context of the Stability and Growth Pact, a clear positive example for Germany's EMU partners. With the prospective medium-term fiscal position now close to balance, Germany should reconsider its focus on targeting nominal fiscal deficits irrespective of cyclical developments. It should craft budgetary policies for the medium term in cyclically adjusted terms, and allow the operation of the automatic fiscal stabilizers if growth deviates from budget projections.

\section{The most welcome feature of the authorities' fiscal policies is the emphasis on} tax reform and targeted cuts in expenditures. The latter are essential both to lend credibility to the overall program and in particular to arrest and reverse the steep rises in labor taxes and especially social security contributions that have compounded the problems of the low skilled. The positive incentive effects of the tax reductions made possible by the spending cuts are amplified by the use of base broadening to facilitate significant reductions in statutory tax rates. There is still important unfinished business, notably as regards personal income taxation, where tax rates will remain relatively high; and policies should therefore remain focused on expenditure restraint that would make room for further headway in lowering the burden of taxes and social contributions.

38. Welcome as they are, however, these policies are unlikely to prove sufficient to ensure lasting reductions in unemployment and greater robustness in performance in the face of shocks. While reducing high labor taxes and social contributions will help the general functioning of the economy, these policies alone do not address the unfavorable dynamics rooted in the differentials in productivity growth between the skilled and the unskilled, and in the greater substitutability with capital of the latter, on the one hand, and the solidarity and parity principles that fix the structure of labor costs on the other. Accordingly, as in the past, the internal fragility of the labor market is likely gradually to increase as the recovery proceeds, and to come to a head in time either as the result of wage push by higherskilled workers or some exogenous shock. In either case, the prospect would be a familiar one: labor shakeout, rising unemployment, fiscal pressures and renewed consolidation, andif German wage developments have demonstration effects elsewhere in the EMU countriesmonetary tightening.

\section{Policies need thus to go beyond seeking to reverse the past effects of such} dynamics and deal directly with their sources in Germany's labor market institutions. In this respect, two of the Government's initiatives-the Alliance for Jobs and the systematic effort to see what Germany can learn from the experiences of other European countriesprovide the basis for the reasoned overall stock taking that is needed and should be actively pursued. From experiences elsewhere in Europe, pertinent points include the following:

- Germany's problems are found throughout Europe, but countries that have addressed them successfully have done so quite differently in the light of their own conditions. Effective solutions for Germany will correspondingly need to take account of its particular circumstances and institutions. 
- The more successful countries have tended to be smaller and/or with more centralized (Denmark and the Netherlands) or decentralized (Switzerland) institutional arrangements than Germany. With Germany something of a halfway house, the Alliance for Jobs should avoid narrow corporatist approaches that could prompt solutions-e.g., trading wage moderation for early retirement-with at best only very short-term benefits. Instead, the key players need to adopt a broader perspective that recognizes the negative externalities associated with the current institutional setup.

- Policy failures have been at least as frequent in Europe as policy successes. A comprehensive approach geared to addressing the incentive issues from all their angles, including intertemporally, is key. Governments typically end up paying part of the bill, e.g., in form of reduced social security contributions. This is worthwhile if it paves the way for dynamic adaptations that offer the firm prospect of strengthened employment and growth over the medium term. Given Germany's fractured decision-making structures, progress on cooperative solutions to the labor market is unlikely unless the government takes a lead role.

40. The core elements of the problem are labor market institutions that fail to match labor costs of the low-skilled with their productivity, and inadequate labor supply incentives. The following measures are thus key ingredients of an appropriate package:

- reductions in labor costs for lower-skilled workers, both through lower (graduated) social contributions and greater flexibility in wage setting and nonwage work arrangements;

- tightened eligibility requirements for recipients of social safety net benefits to spur the unemployed to seek work;

- income safeguards in the form of in-work benefits for lower-paid workers, provided, e.g., through graduated withdrawal of benefits or earned income tax credits;

- a shift to a less comprehensive coverage of public social insurance through the development, as foreshadowed in the June fiscal package, of a private social insurance pillar;

- and a fiscal strategy that permits the package to be financed within an unchanged budgetary envelope, at least over the medium term.

41. The labor market strategy should be complemented by further product market reforms. Recent deregulation steps, notably in the energy and telecommunications sectors, are welcome and are paying off already through sharp price reductions. There is, however, a need for further actions focused on reducing the massive number of business regulations, simplifying approval procedures for start-up companies, encouraging a more service-oriented culture (including by further action to liberalize shop opening hours), and privatizing enterprises, especially at lower levels of government. 
42. Although recent emerging market turbulence has resulted in higher earnings variability and credit quality issues, internationally active banks have increased their provisions against country risk for emerging markets, even as lending to these countries has continued to grow. The banking sectors' exposure to commercial real estate lending, particularly in eastern Germany, however, may be more problematic and the authorities should be vigilant in their assessment of these risks. To this end, the transparency of banks' credit risks should be enhanced by making public information about non-performing loans and provisioning levels, at least at an aggregate banking sector level. The recent introduction of targeted on-site inspections by the supervisory authorities regarding banks' market risk management is welcome and could be broadened to other areas. Measures to open bank ownership structures to market pressures (enhancing corporate control) and to level the playing field across financial institutions would be desirable so as to increase financial sector efficiency.

43. Germany provides data to the Fund that are adequate for surveillance. Partly as a result of the welcome adoption of new European national accounting standards, Germany's economic statistics are in a period of transition, and temporary gaps have arisen. Ongoing revisions of national income and labor market statistics should therefore be completed as soon as possible.

44. Germany's prominent role in strengthening the HIPC initiative is commendable. A reversal in the projected declines in ODA in coming years would be desirable. The authorities are encouraged also to support reductions in still high levels of EU agricultural protection, particularly in the context of the forthcoming WTO negotiations on agricultural trade.

45. Germany's participation in the pilot project for release of Article IV staff reports is welcome. It is proposed that Germany remain on the standard 12-month Article IV consultation cycle. 


\section{Box 1. Long-Term Labor Market Trends ${ }^{1}$}

Germany's adverse aggregate labor market trends since the early 1970 s mask a striking disparity in disaggregated unemployment and employment trends by skills: the labor market problem has been overwhelmingly concentrated in the lower portion of the skill distribution (Box 1 Figures 1 and 2). The unemployment rate for lower-skilled workers in western Germany has risen to a multiple of its level in the mid1970 s, with a particular sharp increase occurring after unification; in 1997, it stood at 26.9 percent, compared to an aggregate unemployment rate of 9.8 percent. Employment of lower-skilled workers fell almost by half during the same period.

Box 1. Figure 1: Unemployment Rates by Skills (in percent) $1 /$

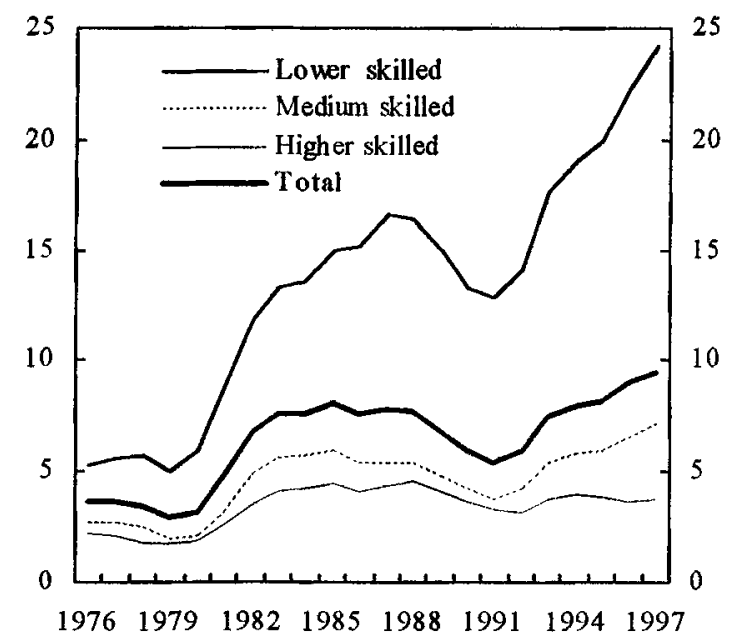

Box 1. Figure 2: Employment Levels by Skills $(1976=100) 1 /$

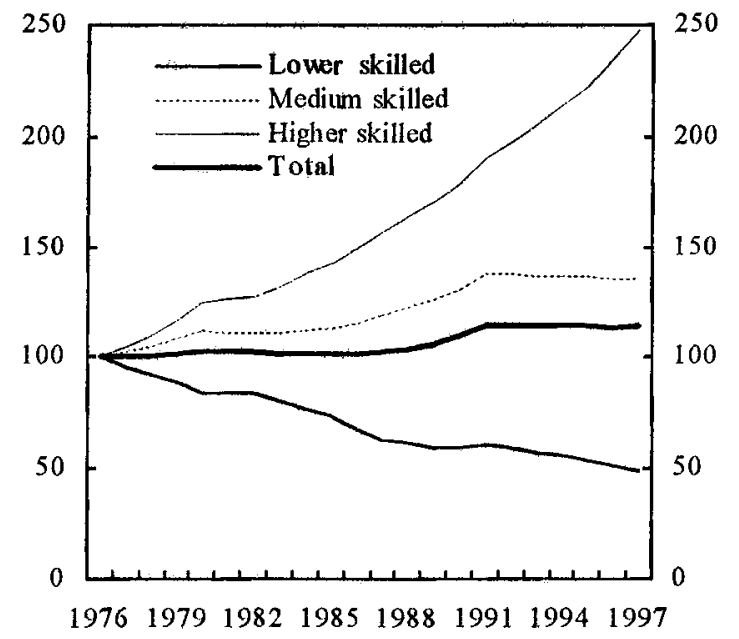

Sources: Reinberg and Rauch (1998), IAB Werkstattbericht No. 15; and staff estimates. 1/ Data refer to western Germany only.

Since the late 1970s, unfavorable labor market trends for the unskilled appear to have been ubiquitous across industrial countries, in large part reflecting skill-biased shifts in labor demand due to technological change or globalization. However, available cross-country data on skill-specific unemployment rates suggest that among industrial countries Germany has experienced one of the most marked relative increases in low skilled unemployment. ${ }^{2}$ Germany's strict adherence to the principle of "relative income solidarity" across workers and a large-scale social insurance system based on the "parity principle" worsened to the already deteriorating situation for lower-skilled/lower-paid workers (the "lowsiders"). With the productivity of lower-skilled workers lagging behind the productivity of the better-educated portion of the work force (the "highsiders") and with wages and social contributions increasing proportionally across the wage distribution, many labor market lowsiders faced insurmountable labor productivity hurdles. The need to finance most social spending by social insurance contributions, which have increased sharply since the 1950s (Box 1 Figure 3), added a vicious circle element to this adverse process from the fiscal side. At the same time, generous non-contributory social benefits (social assistance) raised the effective wage floor over time (Box 1 Figure 4).

Perhaps not surprisingly in view of the wholesale transfer of western Germany's labor market institutions to the new Länder, the adverse labor market trends for the less skilled in eastern Germany have been even more

${ }^{1}$ Chapter I of the Selected Issues Paper contains a more extended presentation of this analysis.

${ }^{2}$ See Manacorda and Petrongolo, 1999, "Skill Mismatch and Unemployment in OECD Countries," Economica, pp. 181-203. 
pronounced, with the unemployment rate of lower-skilled workers rising to 55 percent in 1997, relative to an aggregate unemployment rate of $\mathbf{1 8 . 2}$ percent in the same year.

Box 1. Figure 3: Social Contribution Rate

Box 1. Figure 4: Social Assistance
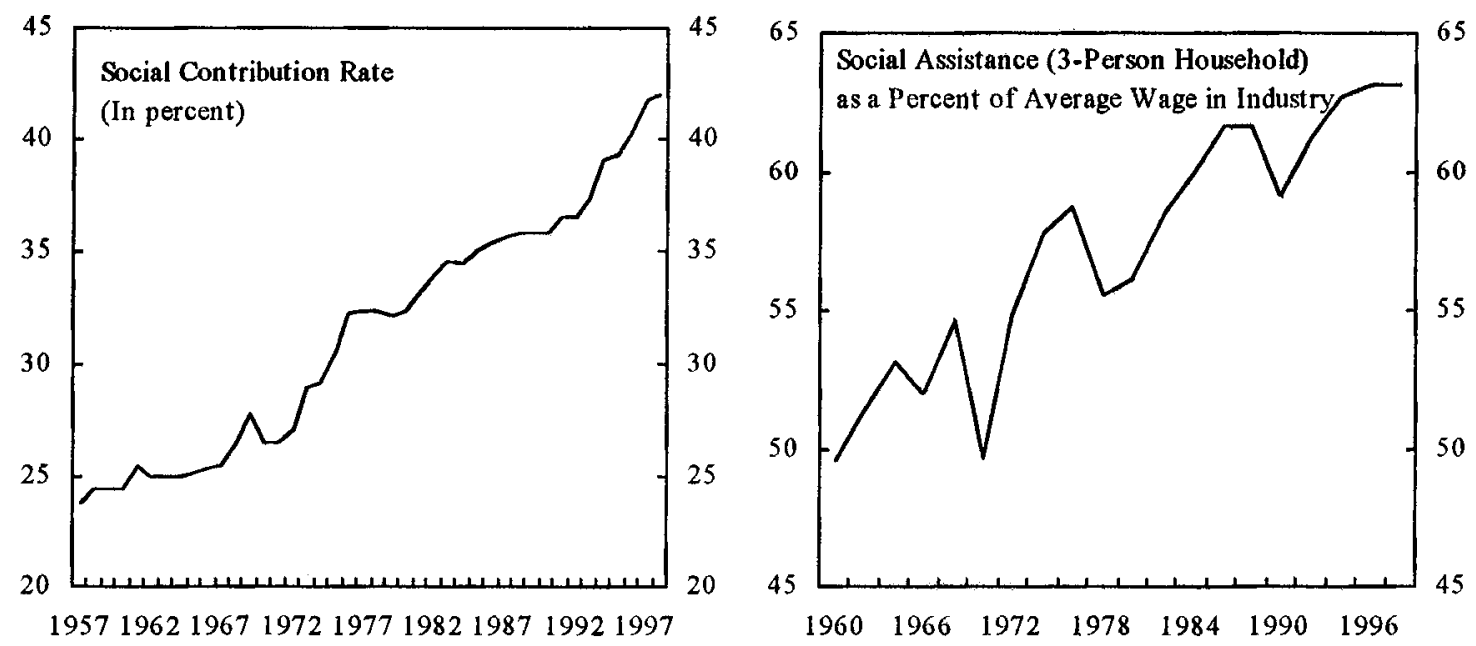

Sources: Ministry of Labor; and Boss (1999), Kiel Working Papers No. 912.

The highsider-lowsider view of the German labor market contrasts with the traditional insider-outsider perspective. The insider-outsider view assumes that the average wage is set to achieve the highest wage increase consistent with continued employment of insiders, ignoring the employment interests of the outsiders. The highsider-lowsider perspective suggests that across-the-board wage increases are benchmarked on the productivity performance of those in the middle and upper portions of the skill distribution, ignoring the lagging productivity performance of the lowsiders. Over the business cycle, Germany's collective bargaining system, although wedded to the principle of income solidarity, responded sensitively to the state of the labor market, as witnessed by the pattern of alternating periods of across-theboard wage moderation (following labor shakeouts and rising unemployment) and across-the-board wage push (during cyclical upturns and following prolonged wage moderation) (Box 1 Figure 4).

Box 1. Figure 5: Aggregate Wage Share and Unemployment Rate 1/

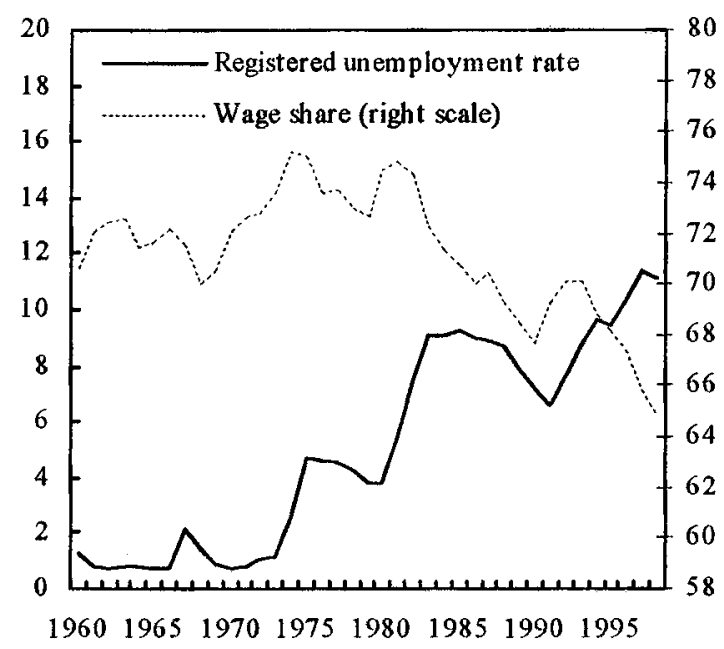

Sources: Deutsche Bundesbank; and staff estimates.

1/ For 1960-90 data refer to western Germany; for 1991-98 data refer to united Germany. 


\section{Box 2. The Cyclical Behavior of Financial Policies ${ }^{1}$}

The malfunctioning labor market complicated the cyclical settings of fiscal and monetary policies. On the side of fiscal policy, the upward ratcheting in the unemployment rate put pressure on the finances of the pay-as-you-go (PAYG) social insurance system and social spending more generally. In addition, prolonged phases of across-the-board wage moderation undermined revenue collections. Over the last 20 years, these forces combined with the urge to "restore order to public finances" following labor market shakeouts (mandated by the constitutional golden rule constraint) led to a procyclical fiscal stance at the central government level. Two exceptional historical events, German unification and the run up to Stage 3 of EMU, also contributed to the observed procyclicality of fiscal policy. As lower government levels traditionally tend to target nominal deficits, the general government's fiscal stance has been strongly procyclical since the beginning of the 1980s (Box 2 Figure 1). Indeed, regression estimates indicate that these procyclical swings in the structural balance offset roughly the automatic fiscal stabilizers during the 1980 s and 1990 s.

Box 2. Figure 1: Fiscal Policy Behavior

Box 2. Figure 2: Monetary Policy Behavior
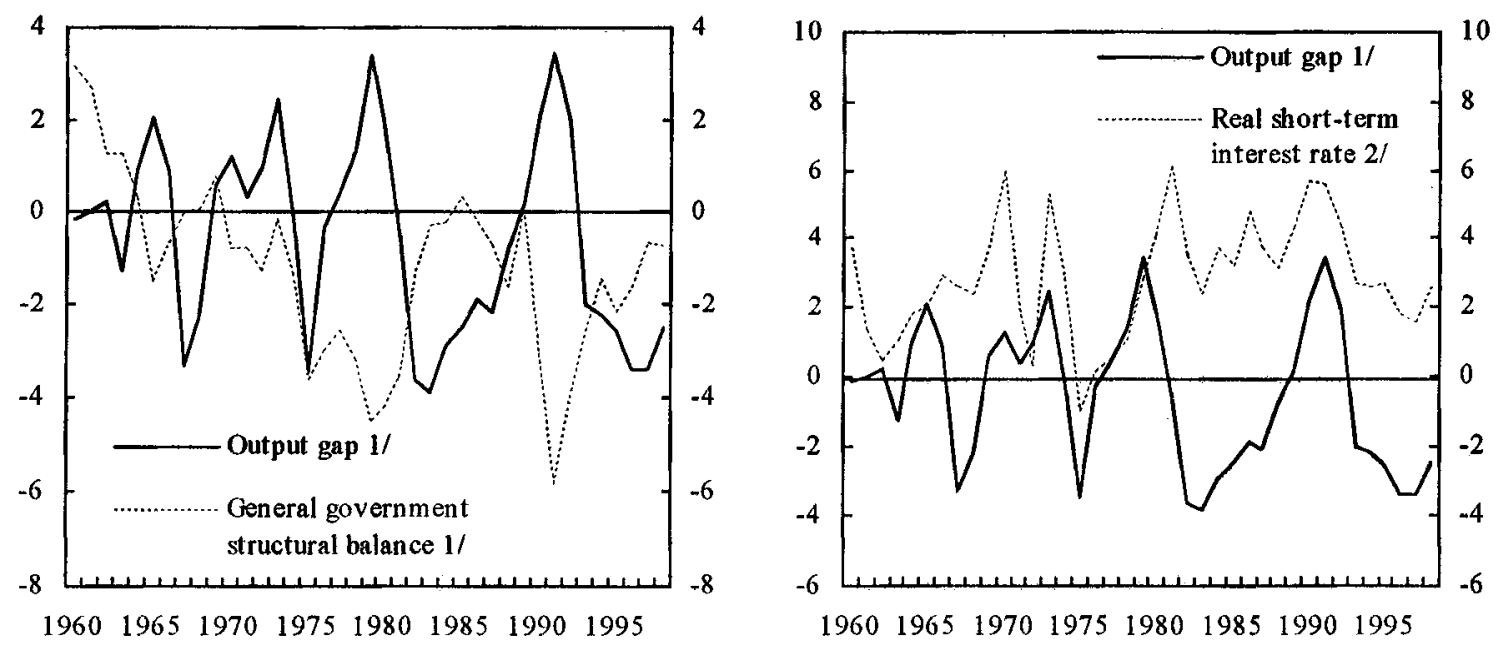

Sources: World Economic Outlook database; and staff estimates.

$1 /$ In percent of potential GDP.

2/ Defined as a difference between 3-month deposit rate and annual CPI inflation rate.

The Bundesbank's monetary policy (until 1998), guided by the clear mandate to preserve mediumterm price stability, was also complicated by the institutional mismatch in the labor market. During cyclical upturns, with unions able to push up wages across the board and a procyclical fiscal stance adding to demand pressures, monetary policy tended to meet perceived inflationary pressures promptly and decisively by a tightening of the monetary stance (Box 2 Figure 2 ). By contrast, and perhaps reflecting an attempt to encourage prolonged across-the board wage moderation, periods of economic slack were characterized by more gradual and what some observers considered a somewhat asymmetric relaxation of the monetary policy stance.

${ }^{1}$ See also Chapter I of the Selected Issues Paper. 


\section{Box 3. Output, Prices, and External Developments}

Just when the German economy appeared by mid-1998 to have shifted to a more dynamic posture, a major contractionary export shock intervened. The impact of the global financial crisis, first visible in a marked decline in foreign orders (Box 3 Figure 1), fed quickly through to exports and business confidence (Box 3 Figure 2). German exports, which had been rising strongly, were hit particularly hard relative to those of other euro area exporters such as France, reflecting both the regional pattern and product composition of German exports. ${ }^{1}$ By the end of 1998, the economy had stalled, with quarter-on-quarter growth (s.a.) negative (-0.3 percent) in the last quarter (Box 3 Figure 3). The abrupt slowdown bottomed out in the first half of 1999: GDP rose by 0.3 percent in the first half on the strength of resilient domestic demand, and leading indicators suggest a marked pickup in the period ahead. The growth setback stifled the first signs in several years of rising employment, but unemployment fell in 1998 and has since been fairly stable ( 9 percent on a standardized basis), helped by active labor market programs and slow labor force growth (Box 3 Figure 4).

Box 3. Figure 1: Foreign Orders and Net Exports

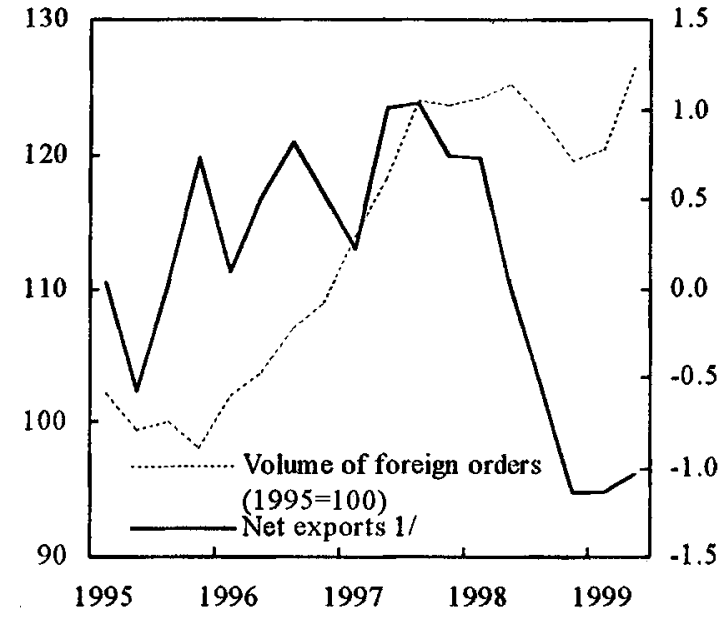

Box 3. Figure 2: Business and Consumer Confidence

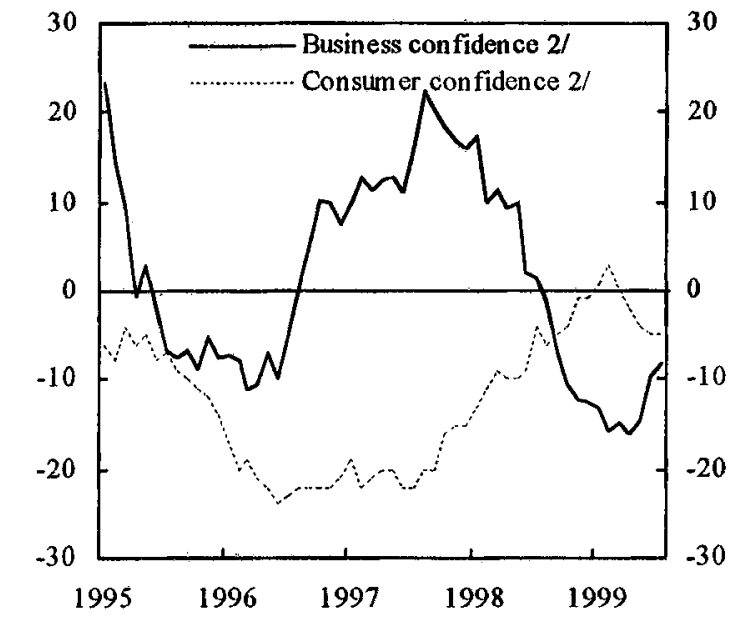

Sources: Deutsche Bundesbank, WEFA database, and staff calculations.

1/ Contribution to GDP growth; right scale.

$2 /$ Percentage of those surveyed expecting an improvement in their situation, less percentage expecting a deterioration.

${ }^{1}$ Emerging markets in Asia and Eastern Europe account for 20 percent of German exports (12 percent for France); (relatively cyclically sensitive) capital and intermediate goods account for 80 percent ( 50 percent for France). 
Box 3. Figure 3: Real GDP and Total

Box 3. Figure 4: Unemployment Rates Domestic Demand
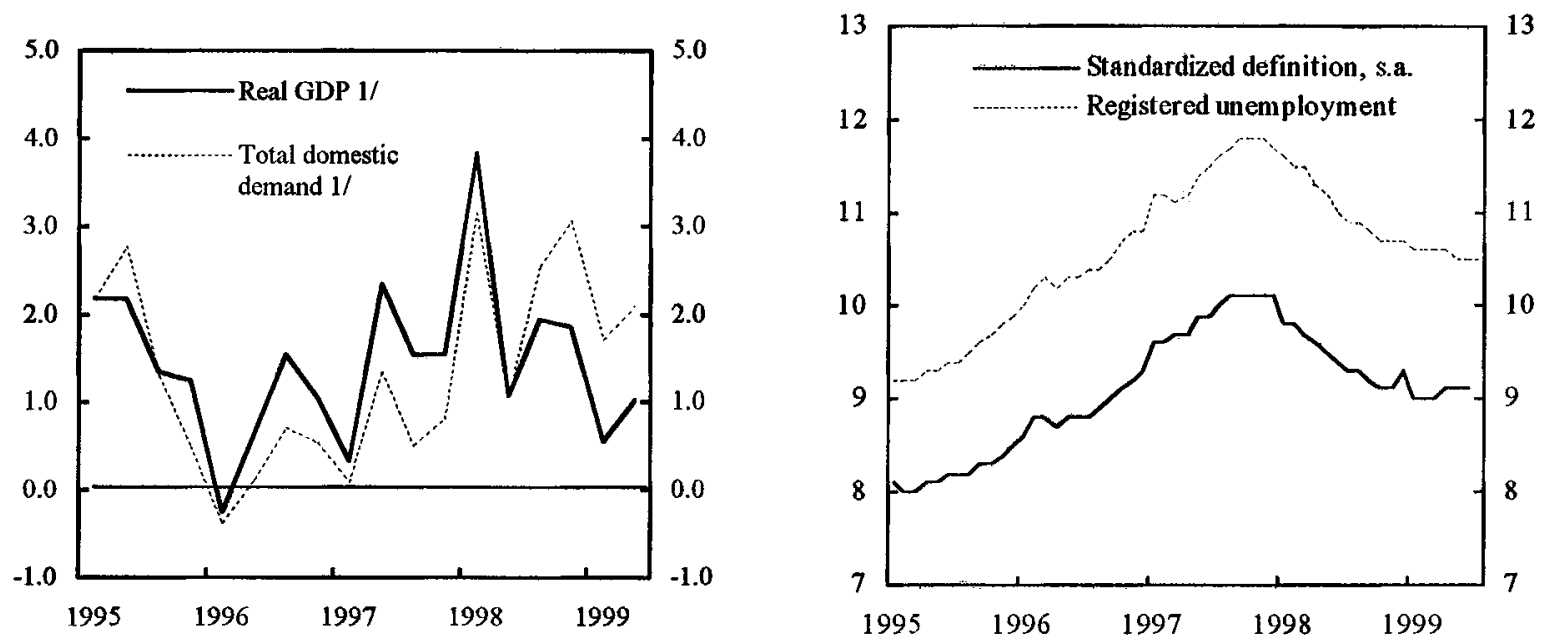

Sources: Deutsche Bundesbank, EUROSTAT database, and staff calculations.

$1 /$ Percent change from corresponding quarter of previous year.

Inflation has been subdued. Annual average CPI inflation has been below 2 percent since 1995 (Box 3 Figure 5). Price stability was underpinned by subdued unit labor cost growth, deregulation in the telecommunications and electricity sectors, and a sharp decline in import prices driven by a decline in world prices of raw materials (Box 3 Figure 6); core inflation (excluding indirect taxes and energy) has decelerated in 1999 to about 0.1 percent.

Box 3. Figure 5: Consumer Prices 1/

Box 3. Figure 6: Import Prices and Unit Labor Costs 1/
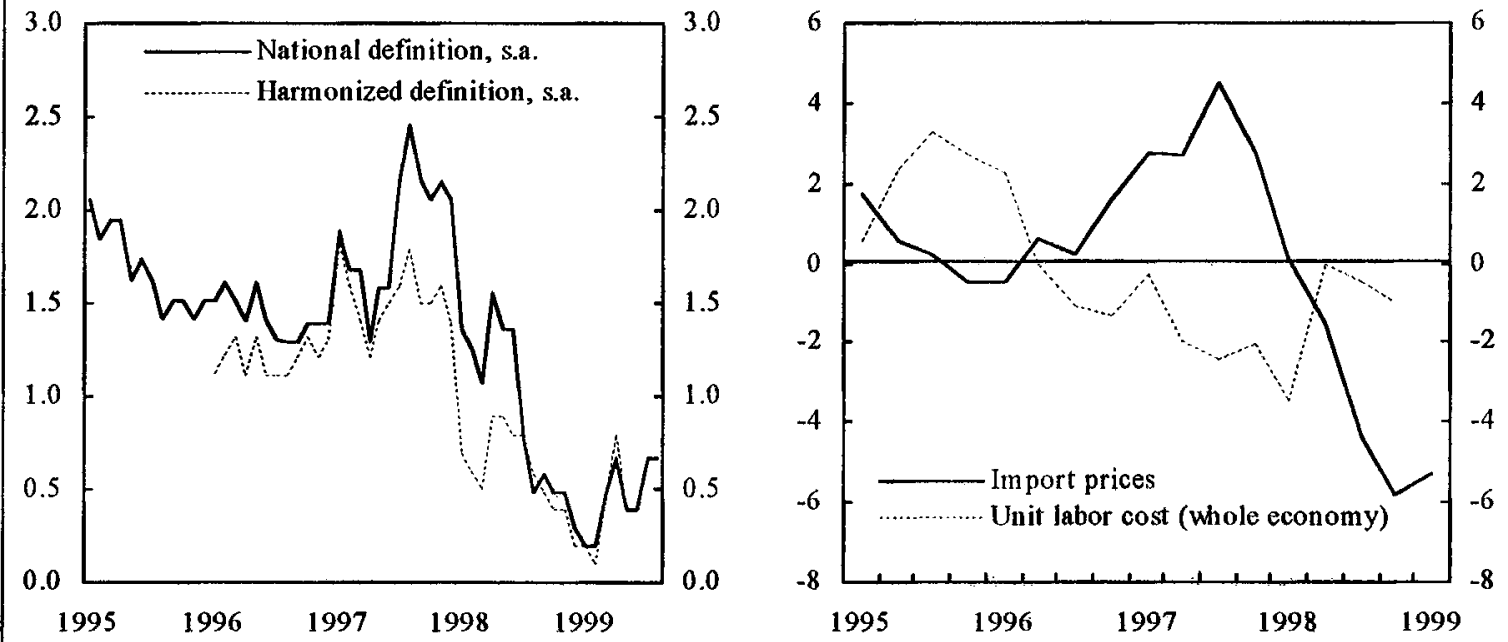

Source: Deutsche Bundesbank.

1/ Percentage change from previous year. 
External competitiveness is satisfactory. The trend improvement-reflecting a combination of falling relative labor costs and a depreciating exchange rate - since the 1995 post-unification nadir was interrupted in 1998 by the effects of nominal exchange rate appreciation, but resumed in 1999 as the euro weakened against other currencies (Box 3 Figures 7 and 8). While recent staff assessments have not suggested multilateral misalignment, the bilateral EMU locking rates agreed in the spring of 1998 left the deutsche mark appearing somewhat overvalued relative to the French franc. The current account was close to balance in 1998, with a terms-of-trade-driven increase in the trade surplus offset by a rise in dividend outflows.

Box 3. Figure 7: Real Effective Exchange Rates $(1990=100)$

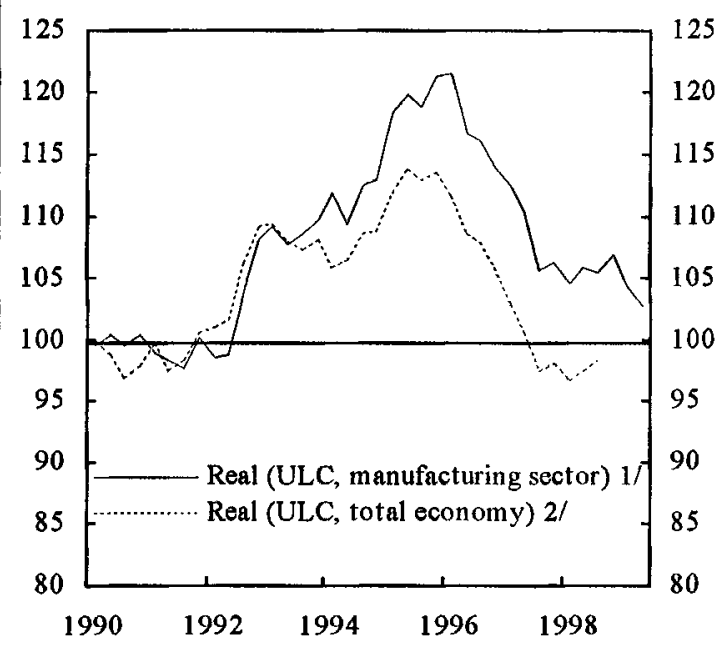

Box 3. Figure 8: Bilateral Real Exchange Rates $(1990=100) 1 /$

Source: IMF, International Financial Statistics; and Deutsche Bundesbank.

1/ Based on unit labor costs in manufacturing.

2/ Based on unit labor costs in whole economy.

EMU has been associated with a massive increase in cross-border capital flows. In the first half of 1999, net capital flows from Germany to other countries amounted to some 19 percent of GDP (as compared to 5 percent of GDP during 1995-96), with most of the sharp increase due to increased capital flows to Germany's EMU partner countries. The rapid pace of increased financial integration in the euro area has been particularly visible in the size of portfolio and foreign direct investment flows. 


\section{Box 4. Monetary and Fiscal Developments}

Monetary conditions have eased significantly since late 1998, reflecting both policy actions and exchange rate developments. Following a 30 basis point increase of the repurchase rate in October 1997 to counter inflationary pressures, the Bundesbank left its key policy rate unchanged at 3.3 percent until December 1998 (Box 4 Figure 1). Long-term bond yields dropped by 120 basis points during the year, reaching a low of 3.6 percent in December; share prices surged in the first half of 1998 (by almost 40 percent) but then lost most of their gains amid the global correction in equity markets. At the same time, declining monthly inflation rates and a modest appreciation of the nominal effective exchange rate contributed to a moderate tightening of monetary conditions. As early indicators of a marked economic slowdown in Germany and elsewhere in the prospective euro area proliferated, the Bundesbank, in coordination with the area's other ten central banks, lowered the repurchase rate by 30 basis points to 3 percent in December 1998. Monetary conditions have eased further in 1999 (Box 4 Figure 2), with the (implicit) DM/dollar exchange rate falling back to its early 1998 level, and the ECB cutting its repurchase rate by 50 basis points to 2.5 percent on April 8 . Asset market conditions have diverged, with share prices regaining upward momentum while bond yields increased to almost 5 percent.

Box 4. Figure 1: Market Interest Rates 1/

Box 4. Figure 2: Monetary Conditions Indices $(1990=0) 2 /$
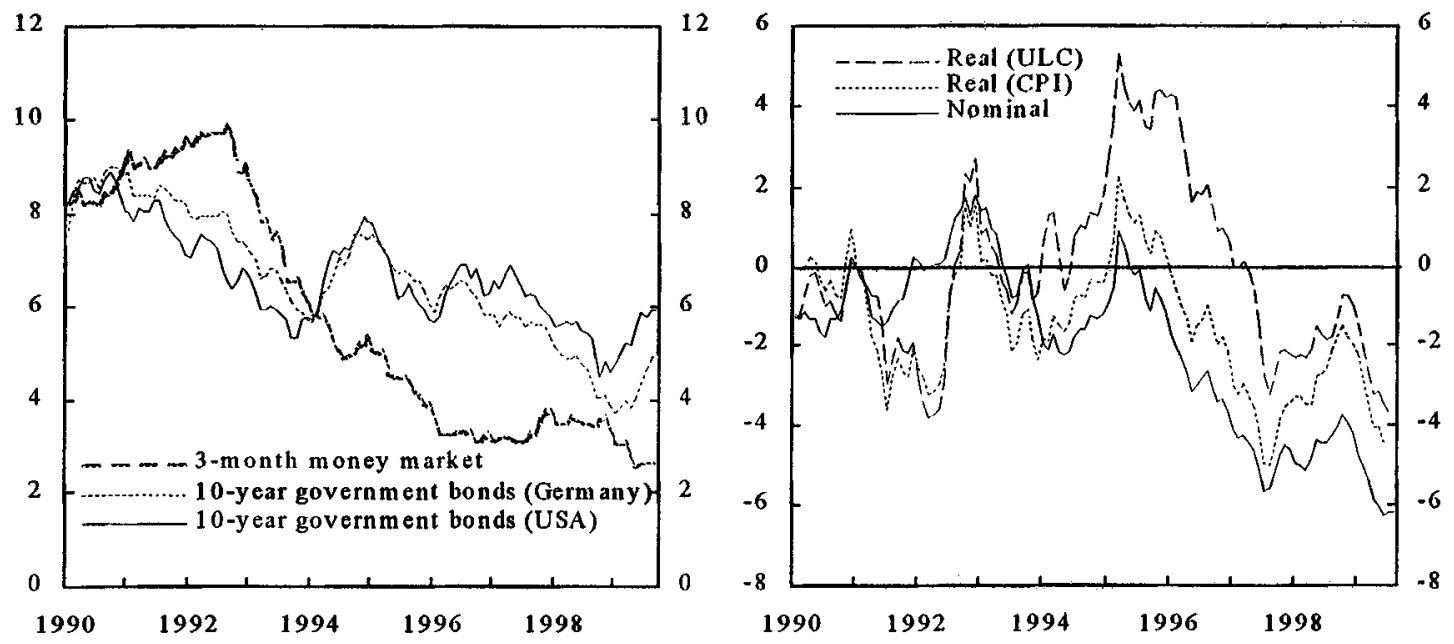

Sources: Deutsche Bundesbank; and IMF staff calculations.

1/ Monthly average data.

2/ The MCIs are constructed with a relative weighting of $1: 2.5$ between the interest rate and the effective exchange rate -- a one percentage point change in the interest rate is equivalent to a 2.5 percentage point change in the exchange rate. The MCI is scaled to equal zero in January 1991 and upward movements in the index denote tighter monetary conditions.

3/ Real 3-month rate and real effective exchange rate (ULC).

4/ Real 3-month rate and real effective exchange rate (CPD).

5/ Nominal 3-month rate and nominal effective exchange rate.

Fiscal policy has been guided by the Stability and Growth Pact and the constitutional requirement to restrict federal borrowing to investment spending. The general government deficit in 1999 is projected at just under 2 percent of GDP, in line with budget estimates and the January 1999 Stability Program. While activity has been weaker than anticipated (the budget was based on GDP growth of 2 percent), the fiscal position has benefited from interest savings and a composition of aggregate demand that has favored more highly-taxed components (notably private consumption); also recent data indicate a more favorable outturn in 1998 than envisaged at the time of the 1999 budget preparation. Overall, the staff estimates the 1999 fiscal stance as neutral (Table 1). 
Box 4. Table 1. Germany: Medium-Term Projections of General Government Finances, 1994-2004 1/

(In percent of GDP)

\begin{tabular}{|c|c|c|c|c|c|c|c|c|c|c|c|}
\hline & 1994 & 1995 & 1996 & 1997 & 1998 & $\begin{array}{l}1999 \\
\text { Proj. }\end{array}$ & $\begin{array}{l}2000 \\
\text { Proj. }\end{array}$ & $\begin{array}{l}2001 \\
\text { Proj. }\end{array}$ & $\begin{array}{l}2002 \\
\text { Proj. }\end{array}$ & $\begin{array}{l}2003 \\
\text { Proj. }\end{array}$ & $\begin{array}{l}2004 \\
\text { Proj. }\end{array}$ \\
\hline \multicolumn{12}{|l|}{ Official fiscal targets $2 /$} \\
\hline Federal government & -1.2 & -1.5 & -1.9 & -1.7 & -1.8 & -2 & $-1 \frac{1}{2}$ & -1 & -1 & $\ldots$ & $\ldots$ \\
\hline States and communes & -1.4 & -1.3 & -1.1 & -1.1 & -0.1 & $-1 / 2$ & $-1 / 2$ & $-1 / 2$ & 0 & $\ldots$ & \\
\hline Social insurance system & 0.1 & -0.4 & -0.3 & 0.1 & 0.2 & $1 / 2$ & 0 & 0 & 0 & $\ldots$ & $\ldots$ \\
\hline Revenue & 46.5 & 46.3 & 46.9 & 46.6 & 46.6 & 47.1 & 46.9 & 46.5 & 46.1 & 46.2 & 46.2 \\
\hline Expenditure & 49.0 & 49.5 & 50.3 & 49.2 & 48.3 & 49.0 & 48.0 & 47.3 & 46.6 & 46.4 & 46.3 \\
\hline Interest payments & 3.4 & 3.7 & 3.7 & 3.7 & 3.6 & 3.5 & 3.4 & 3.2 & 3.1 & 3.1 & 3.1 \\
\hline Balance & -2.5 & -3.2 & -3.4 & -2.6 & -1.7 & -1.9 & -1.1 & -0.8 & -0.5 & -0.2 & -0.1 \\
\hline Federal government & -1.2 & -1.5 & -1.9 & -1.7 & -1.8 & $\cdots$ & $\cdots$ & $\cdots$ & $\cdots$ & $\cdots$ & $\ldots$ \\
\hline States and communes & -1.4 & -1.3 & -1.1 & -1.1 & -0.1 & $\cdots$ & $\cdots$ & $\cdots$ & $\ldots$ & $\ldots$ & $\cdots$ \\
\hline Structural balance 4/ & -2.3 & -2.9 & -2.3 & -1.1 & -0.3 & -0.3 & 0.2 & 0.1 & -0.2 & -0.1 & -0.1 \\
\hline Interest payments 4/ & 3.4 & 3.7 & 3.6 & 3.6 & 3.5 & 3.4 & 3.3 & 3.2 & 3.1 & 3.1 & 3.1 \\
\hline Fiscal impulse 5/ & -0.7 & 0.3 & -0.6 & -1.1 & -0.7 & 0.0 & -0.4 & 0.3 & 0.4 & -0.1 & 0.0 \\
\hline Output gap 4/ & 0 & -0.3 & -1.7 & -2.3 & -2.2 & -3.0 & -2.6 & -1.7 & -0.6 & -0.2 & 0.0 \\
\hline Real GDP growth (in percent) & 2.3 & 1.7 & 0.8 & 1.5 & 2.2 & 1.4 & 2.5 & 3.0 & 3.2 & 2.5 & 2.3 \\
\hline
\end{tabular}

Sources: Ministry of Finance; and staff projections.

1/ Data are based on the European System of Integrated Economic Accounts 1995 (ESA95).

2/ Based on Germany's "Fiscal Stability Programme," as submitted to the Council of Ministers and the European Commission in January 1999 . Data through 1998 are latest official estimates released in September 1999.

3/ Beginning in 1995, the debt and debt-service obligations of the Treuhandanstalt (and various other agencies) were taken over by the general government.

4/ In percent of potential GDP.

5/ Change in primary structural balance; minus sign indicates withdrawal of stimulus. 


\section{Box 5. Fiscal Policy and Tax Reform Initiatives}

\section{The June consolidation package}

The targeted spending cuts announced in June would reduce federal spending, relative to previous plans, by DM 30 billion ( $3 / 4$ percent of GDP) in 2000 and 1 percent of GDP in 2003. The package reduces social transfers ( 32 percent of total 2003 savings), public consumption ( 30 percent, about half of which is wages), and subsidies and other transfers ( 12 percent); the remainder are mainly current expenditure savings agreed but yet to be allocated across economic categories. Among the large number of expenditure cuts, the most significant are: indexing pensions and social benefits in 2000 and 2001 to consumer price inflation, rather than to average post-tax wages; limiting increases in civil service salaries also to inflation; and linking social insurance contributions on behalf of those receiving unemployment assistance to their benefits rather than their previous earnings. The change in benefit indexation has the grcatest impact at the general government level, where it affects spending financed by social contributions as well as by Federal budget transfers.

\section{Tax reform}

The March 1999 legislation consists of eight main measures: (i) an increase in standard income tax deductions from DM 12,360 to DM 14,000; (ii) a cut in the entry rate on personal income from 25.9 to 19.9 percent; (iii) a cut in the top marginal rate on personal income from 53 to 48.5 percent; (iv) a reduction in the top marginal rate on non-incorporated business income from 47 to 43 percent; (v) a cut in the corporate income tax on retained profits from 45 to 40 percent; (vi) some seventy base-broadening measures; (vii) an increase in child allowances, and; (viii) an increase in energy taxes (ecotax) to finance a reduction in social contribution rates. Some of these measures are phased in during the period until 2002.

The June 1999 tax reform proposal, scheduled for legislative consideration in the fall, features: (i) a further relief for families with children as required by the Constitutional Court; (ii) a large business income tax reform to begin in 2001, and; (iii) the second phase of ecotax reform. The business income tax proposal would reduce corporate and non-corporate tax rates to 25 percent, which - together with the local trading tax-would result in a top rate on retained profits of 35-39 percent (down from over 50 percent). Full imputation (under which taxes on dividends paid by the corporation are credited, but dividends are subject to personal income tax) would be abolished; instead half of distributed profits would be subject to the personal income tax.

The March legislation is estimated to lower the burden on households by $1 / 2$ percent of GDP over the medium term, while the June proposal would reduce business income taxes by $1 / 4$ percent of GDP.

\section{Overall fiscal position}

The German authorities will submit a revised Stability Program in late 1999. The original program, presented last January, targets a general government deficit of 2 percent of GDP in 2000 and 1 percent in 2002. The staff's current projections, taking account of the June package, show a decline in the general government deficit to $1 / 2$ percent of GDP in 2002 and less than $1 / 4$ percent thereafter. The fiscal stance, as measured by the primary structural balance, shows a withdrawal of stimulus of 0.4 percent of GDP in 2000 . Policy would then become stimulative, reflecting the 2001 business income tax reform proposed in June 1999 and the 2002 household tax reductions legislated in March 1999. 


\section{Box 6. Labor Market Policies in Selected Continental European Countries}

Several continental European countries have adopted labor market policies that may offer useful benchmarks for Germany's reform agenda. This box focuses on three selected cases - the Netherlands, Denmark, and Switzerland. A common thread of these cases is that policies are mutually complementary, rooted in social consensus, and consistent with equity aims that are broadly similar to Germany's own.

With the Netherlands facing crisis conditions in the early $1980 \mathrm{~s}$, the authorities and social partners agreed on wide-ranging labor market measures that relied on: (i) strong complementarity of the reform measures: benefit reform contributed to spending restraint, facilitating fiscal consolidation and cuts in the tax wedge; tax cuts and benefit reforms favored wage moderation that helped strengthen labor demand; buoyant employment boosted the tax base, setting in motion a virtuous circle in the labor market and public finances; and (ii) social consensus fostered by the authorities' consultative style and the new terms of the "game" implied by the tax and labor market reforms. The new rules then delivered growth, jobs, and core social protection, cementing popular support.

Denmark's labor market policies have focused on improving employability of workers and on strengthening incentives and making job search and matching more efficient. With radical reductions in benefit rates and minimum wages not considered feasible politically, policy measures have focussed on tightening of eligibility and activation requirements and reducing the duration of benefits. There are clear indications that the measures to strengthen work incentives affected behavior and improved the functioning of the labor market.

The case of Switzerland's labor market institutions is of particular interest. Apart from the obvious disparity in size, the Swiss and German economies share a number of common features: large, export-oriented, high-wage manufacturing sectors; high saving rates and similar education and training systems; similar exposure to demand and technology shocks; and highly decentralized political systems that require broad consensus for implementing reforms. However, the key institutional differences that appear to support Switzerland's relatively favorable labor market performance are: (i) a decentralized wage bargaining system that sets wages in accordance with conditions at the firm level; (ii) a multi-pillar social insurance system that necessitates significantly lower contribution rates, with the public pillar providing mandatory basic insurance and private pillars offering supplementary coverage; (iii) limits on duration of unemployment benefits coupled with a requirement to participate in active labor market programs; and (iv) lower employment protection and less generous nonwage benefits. At the same time, and reflecting a strongly held social consensus, social benefit replacement rates are, as in Germany, relatively high. 
Germany: Basic Data

Total area

Total population (1998)

GNP per capita (1998)
357,041 square kilometers

82.0 million

US\$26, 189

\begin{tabular}{|c|c|c|c|c|c|}
\hline & 1996 & 1997 & 1998 & $1999 \mathrm{l} /$ & $2000 \mathrm{l} /$ \\
\hline & \multicolumn{5}{|c|}{ (Percentage change at 1995 prices) } \\
\hline \multicolumn{6}{|l|}{ Demand and supply } \\
\hline Private consumption & 0.8 & 0.7 & 2.3 & 2.1 & 2.4 \\
\hline Public consumption & 2.1 & -1.1 & 0.5 & 0.9 & 0.5 \\
\hline Gross fixed investment & -1.1 & 0.5 & 1.4 & 2.9 & 3.4 \\
\hline Construction & -2.9 & -1.4 & -3.9 & -1.6 & 1.1 \\
\hline Machinery and equipment & 1.2 & 3.4 & 9.2 & 8.0 & 5.6 \\
\hline Final domestic demand & 0.6 & 0.3 & 1.7 & 2.1 & 2.2 \\
\hline Inventory accumulation $2 /$ & -0.4 & 0.4 & 0.7 & -0.1 & 0.0 \\
\hline Total domestic demand & 0.3 & 0.7 & 2.5 & 2.0 & 2.2 \\
\hline \multicolumn{6}{|l|}{ Exports of goods and } \\
\hline nonfactor services & 5.1 & 10.9 & 7.0 & 2.2 & 7.4 \\
\hline \multicolumn{6}{|l|}{ Imports of goods and } \\
\hline nonfactor services & 3.2 & 8.3 & 8.5 & 4.6 & 6.3 \\
\hline Foreign balance $2 /$ & 0.5 & 0.8 & -0.3 & -0.6 & 0.4 \\
\hline \multirow[t]{2}{*}{ GDP } & 0.8 & 1.5 & 2.2 & 1.4 & 2.5 \\
\hline & \multicolumn{5}{|c|}{ (In millions, unless otherwise indicated ) } \\
\hline \multicolumn{6}{|l|}{ Employment and unemployment } \\
\hline Labor force & 39.6 & 39.7 & 39.6 & 39.5 & 39.4 \\
\hline Employment 3/ & 36.1 & 35.8 & 35.9 & 36.0 & 36.1 \\
\hline Unemployed 4/ & 3.5 & 3.9 & 3.7 & 3.5 & 3.3 \\
\hline Standardized unemployment rate & 8.8 & 9.8 & 9.4 & 8.9 & 8.5 \\
\hline Registered unemployment rate & 10.4 & 11.4 & 11.1 & 10.5 & 10.0 \\
\hline Western Germany & 9.1 & 9.8 & 9.4 & $\ldots$ & $\ldots$ \\
\hline \multirow[t]{2}{*}{ Eastern Germany } & 15.7 & 18.1 & 18.2 & $\cdots$ & $\cdots$ \\
\hline & \multicolumn{5}{|c|}{ (Percentage change) } \\
\hline \multicolumn{6}{|l|}{ Prices and incomes } \\
\hline GDP deflator & 1.0 & 0.8 & 1.0 & 1.0 & 1.2 \\
\hline Consumer price index (national definition) & 1.4 & 1.9 & 1.0 & 0.6 & 1.0 \\
\hline Consumer price index (harmonized) & 1.2 & 1.5 & 0.6 & 0.4 & 0.8 \\
\hline Average hourly earnings (industry) & 4.3 & 1.1 & 1.7 & $\ldots$ & $\ldots$ \\
\hline Unit labor cost (total economy) & 0.6 & -0.8 & -0.4 & $\ldots$ & $\ldots$ \\
\hline Real disposable income $5 /$ & 1.8 & 0.1 & 1.9 & 2.4 & 2.9 \\
\hline Personal saving ratio (in percent) & 11.1 & 10.5 & 10.2 & 10.4 & 10.8 \\
\hline
\end{tabular}

1/ Staff projections.

2/ Change as percent of previous year's GDP.

3/ According to place of residence.

4/ On national accounts basis (ESA95); Unemployment as defined by the international labor organization (ILO).

5/ Deflated by the national accounts deflator for private consumption. 
Germany: Basic Data (concluded)

\begin{tabular}{|c|c|c|c|c|c|}
\hline & 1996 & 1997 & 1998 & $19991 /$ & $20001 /$ \\
\hline Public finances $2 /$ & \multicolumn{5}{|c|}{ (In billions of deutsche marks) } \\
\hline General government & & & & & \\
\hline Expenditure & 1,804 & 1,805 & 1,829 & 1,896 & 1,928 \\
\hline (In percent of GDP) & 50.3 & 49.2 & 48.3 & 49.0 & 48.0 \\
\hline Revenue & 1,683 & 1,709 & 1,765 & 1,823 & 1,884 \\
\hline (In percent of GDP) & 46.9 & 46.6 & 46.6 & 47.1 & 46.9 \\
\hline Financial balance & -121 & -97 & -65 & -73 & -44 \\
\hline (In percent of GDP) & -3.4 & -2.6 & -1.7 & -1.9 & $-1,1$ \\
\hline \multicolumn{6}{|l|}{ Federal government } \\
\hline Financial balance & -78.5 & -63.5 & -56.4 & -53.5 & -49.5 \\
\hline (In percent of GDP) & -2.2 & -1.7 & -1.5 & -1.4 & -1.2 \\
\hline General government debt & 2,180 & 2,255 & 2,312 & 2,347 & 2,391 \\
\hline (In percent of GDP) & 60.8 & 61.5 & 61.1 & 60.6 & 59.5 \\
\hline \multicolumn{6}{|l|}{ Balance of payments } \\
\hline Trade balance $3 /$ & 94.3 & 110.3 & 123.8 & 110.1 & 123.0 \\
\hline Services balance & -53.1 & -56.9 & -61.8 & -65.4 & -65.6 \\
\hline Net private transfers & -16.0 & -16.0 & -15.9 & $\ldots$ & $\ldots$ \\
\hline Net official transfers & -35.3 & -36.8 & -37.4 & $\ldots$ & $\ldots$ \\
\hline Current account & -8.4 & -2.4 & -7.4 & -3.8 & 8.3 \\
\hline (In percent of GDP) & -0.2 & -0.1 & -0.2 & -0.1 & 0.2 \\
\hline Foreign exchange reserves (e. o. p.) & 119.5 & 126.9 & 134.0 & $\ldots$ & $\ldots$ \\
\hline Monetary data & \multicolumn{5}{|c|}{ (Percentage changes, end of period) } \\
\hline Money and quasi-money (M3) & 7.9 & 4.6 & 5.9 & $\ldots$ & $\ldots$ \\
\hline Domestic bank lending & 7.6 & 6.0 & 6.4 & $\ldots$ & $\ldots$ \\
\hline \multicolumn{6}{|l|}{ Of which lending to: } \\
\hline Public authorities & 7.7 & 5.4 & 2.3 & $\ldots$ & ... \\
\hline Private nonbanks & 7.6 & 6.2 & 7.6 & $\ldots$ & $\ldots$ \\
\hline Interest rates & \multicolumn{5}{|c|}{ (Period averages in percent) } \\
\hline Three-month interbank rate $4 /$ & 3.3 & 3.3 & 3.5 & 2.7 & ... \\
\hline Yield on ten-year government bonds 4 / & 6.2 & 5.7 & 4.6 & 5.1 & $\ldots$ \\
\hline Exchange rates & \multicolumn{5}{|c|}{ (Levels) } \\
\hline DM per US\$ (end of period) & 1.55 & 1.79 & 1.67 & $\cdots$ & $\ldots$ \\
\hline DM per US\$ (annual average) & 1.50 & 1.73 & 1.76 & $\ldots$ & $\ldots$ \\
\hline Euro per US\$ (annual average) & 0.79 & 0.88 & 0.89 & 0.96 & $\ldots$ \\
\hline Nominal effective rate $(1990=100) 5 /$ & 108.9 & 103.9 & 104.1 & 101.9 & $\ldots$ \\
\hline Real effective rate $(1990=100) 5 /$ & 117.0 & 108.7 & 105.7 & 101.3 & $\ldots$ \\
\hline
\end{tabular}

1/ Staff projections.

2/ Data for federal government are on an administrative basis.

Data for the general government are on a national accounts basis. Debt data are end-of-year data for the general government in accord with Maasiricht definitions.

3/ Including supplementary trade items.

4/ Data for 1999 refer to September 13, 1999.

5/ Data for 1999 refer to August 1999. 


\section{Germany: Fund Relations}

(As of August 31, 1999)

\section{Membership Status:}

Germany became a member of the Fund on August 14, 1952. Germany has accepted the obligations of Article VIII, Sections 2, 3, and 4.

II. General Resources Account:

Quota

Fund holdings of currency

Reserve position in Fund

Operational budget transfers (net)

III. SDR Department:

Net cumulative allocation Holdings
SDR Million

$13,008.20$

$8,030.98$

$4,977.24$

$-225.00$

SDR Million

$1,210.76$

$1,349.84$

None

IV. Outstanding Purchases and Loans:

V. Financial Arrangements:

VI. Projected Obligations to Fund:

VII. Exchange Rate Arrangement:
\% Quota

100.0

61.7

38.3

$\%$ Allocation

100.0

111.5

Since January 1, 1999, Germany is a member of the European Economic and Monetary Union; the deutsche mark entered EMU at a value of DM 1.95583 per euro.

Germany maintains exchange restrictions against Iraq pursuant to U.N. Security Council Resolution No. 661, and against the Federal Republic of Yugoslavia (Serbia/Montenegro) pursuant to U.N. Security Council Resolution No. 757. These restrictions were notified to the Fund under Decision No. 144. In accordance with U.N. Security Council Resolution No. 1022, the financial sanctions against the Federal Republic of Yugoslavia (Serbia/Montenegro) were suspended with effect from November 22, 1995. The sanctions against the areas of Bosnia and Herzegovina that were controlled by the Serbs were suspended on February 27, 1996.

\section{Article IV Consultations:}

Germany is on a 12-month consultation cycle. The staff report for the last Article IV Consultation (SM/98/203) was discussed at EBM/98/92 (September 2, 1998). 


\section{GERMANY: STATISTICAL APPENDIX}

Germany has a full range of statistical publications and has subscribed to the Fund's Special Data Dissemination Standard (SDDS). The authorities make full use of the Internet to facilitate on-line access to data and press information, especially by the Federal Statistical Office, the Bundesbank, the Ministry of Finance, and the Bureau for Labor.

Since the beginning of 1999, Germany's monetary and banking statistics methodology has changed to reflect the standards of the European Monetary Union. The Bundesbank has recently also taken steps to further harmonize the presentation of the balance of payments data with the prescriptions of the fifth edition of the IMF's Balance of Payments Manual.

Nonetheless, three particular aspects of Germany's data situation impede data analysis:

- $\quad$ Since the adoption of the European System of Integrated Economic Accounts 1995 (ESA95) in April of this year, analysis is hampered by lacunae in the data: (i) ESA95 data are presently not available for the household and corporate sectors; and (ii) ESA95 data are only available from 1991 onward. Budgetary constraints are likely to hinder the adoption of ESA95 for pre-1991 data, thus severely restricting the scope for time series analysis of German data.

- The adoption of ESA95 also led to a discontinuation of the publication of separate national accounts data for western and eastern Germany. Although regional economic indicators may help to bridge some of the information gap, the monitoring of the convergence process in the new Länder will likely be impeded.

- The coverage of Germany's labor market statistics remains incomplete at the lower end of the labor market. In particular, although official employment statistics included an estimate of small-time jobs-jobs that require less than 15 hours of work time per week and (until April 1999) earned less than DM 620 per month-the estimate appears to have vastly underestimated the level and rate of increase of this type of job category. In April 1999, the Federal Statistical Office published a preliminary revision of the employment series for 1991-98, indicating that employment levels were considerably higher than previously shown. For example, while the unrevised statistics put total employment in 1998 at 33.9 million, the revised employment statistics now report a figure of 36.0 million. However, there is considerable uncertainty about the need for further revisions of the employment statistics as some survey data appear to suggest that the number of small-time jobs may well exceed the number reflected in the latest revision. Moreover, since January 1999, the Federal Statistical Office has stopped the publication of monthly employment statistics due to a change-over in the reporting procedure for social insurance purposes (the exemption of small-time (DM 630) jobs from social insurance contributions was eliminated in April 1999). 
Germany: Core Statistical Indicators

(As of end-August 1999)

\begin{tabular}{|c|c|c|c|c|c|c|c|c|}
\hline & $\begin{array}{c}\text { Exchange } \\
\text { Rates }\end{array}$ & $\begin{array}{c}\text { Interest } \\
\text { Rates }\end{array}$ & $\begin{array}{c}\text { Consumer } \\
\text { Price } \\
\text { Index }\end{array}$ & $\begin{array}{l}\text { Exports/ } \\
\text { Imports }\end{array}$ & $\begin{array}{l}\text { Current } \\
\text { Account } \\
\text { Balance }\end{array}$ & $\begin{array}{c}\text { Overall } \\
\text { Govern- } \\
\text { ment } \\
\text { Balance }\end{array}$ & $\begin{array}{l}\text { GDP/ } \\
\text { GNP }\end{array}$ & $\begin{array}{c}\text { External } \\
\text { Debt/ } \\
\text { Debt } \\
\text { Service }\end{array}$ \\
\hline $\begin{array}{l}\text { Date of Latest } \\
\text { Observation }\end{array}$ & $8 / 31 / 99$ & $8 / 31 / 99$ & $7 / 99$ & $6 / 99$ & $6 / 99$ & 1998 & $1999 \mathrm{Q} 1$ & $6 / 98$ \\
\hline Date Received & $8 / 31 / 99$ & $8 / 31 / 99$ & $8 / 11 / 99$ & $8 / 10 / 99$ & $8 / 10 / 99$ & $1 / 20 / 99$ & 6/8/99 & $4 / 99$ \\
\hline $\begin{array}{l}\text { Frequency } \\
\text { of Data }\end{array}$ & Daily & Daily & Monthly & Monthly & Monthly & Annual & Quarterly & Semiannual \\
\hline $\begin{array}{l}\text { Frequency of } \\
\text { Reporting }\end{array}$ & Daily & Daily & Monthly & Monthly & Monthly & Annual & Quarterly & Monthly \\
\hline $\begin{array}{l}\text { Source of } \\
\text { Update }\end{array}$ & $\begin{array}{l}\text { Bundesbank, } \\
\text { website }\end{array}$ & $\begin{array}{l}\text { Bundesbank, } \\
\text { website }\end{array}$ & $\begin{array}{l}\text { Statistical } \\
\text { Office, website }\end{array}$ & $\begin{array}{l}\text { Statistical } \\
\text { Office, website }\end{array}$ & $\begin{array}{l}\text { Statistical } \\
\text { Office, website }\end{array}$ & \begin{tabular}{|l|} 
Statistical \\
Office
\end{tabular} & $\begin{array}{l}\text { Statistical } \\
\text { Office, website }\end{array}$ & $\begin{array}{l}\text { Bundesbank, } \\
\text { website }\end{array}$ \\
\hline $\begin{array}{l}\text { Mode of } \\
\text { Reporting }\end{array}$ & Electronic & Electronic & Electronic & Electronic & Electronic & Electronic & Electronic & Electronic \\
\hline Confidentiality & None & None & None & None & None & None & None & None \\
\hline $\begin{array}{l}\text { Frequency of } \\
\text { Publication }\end{array}$ & Daily & Daily & Monthly & Monthly & Monthly & Annual & Quarterly & Monthly \\
\hline
\end{tabular}




\section{Statement by the IMF Staff Representative \\ October 20, 1999}

This statement provides information on economic and financial developments that has become available since the staff report for the 1999 Article IV consultation with Germany (SM/99/249) was issued on September 30, 1999. This information does not alter the thrust of the staff appraisal.

1. Recent indicators support the strengthening of activity for the near term envisaged in the staff report, with GDP growth projected to pick up from $1 \frac{1}{2}$ percent in 1999 to $2 \frac{1}{2}$ percent next year.

- Business confidence, as measured by the IFO business climate index, improved further in August to 95.3, from 93.6 in July. Confidence has now recovered almost to the level of mid-1998, before German exports were hit by the emerging market shock.

- Manufacturing orders rose for the third month in a row in August and were 9 percent higher than a year earlier, with foreign orders particularly strong. Manufacturing output increased by $2 \frac{1}{2}$ percent between June and August.

- The long-dormant construction sector shows signs of recovery, with latest data on orders showing a rise of $2 \frac{1}{2}$ percent from the previous month.

- Retail sales have firmed, and in August were 11/2 percent higher than a year earlier.

2. In the labor market, unemployment has remained stable in recent months at a standardized rate of about 9 percent, helped by active labor market measures including the authorities' initiative to reduce youth unemployment. Monthly employment statistics have not been published since the beginning of the year owing to a changeover in social insurance reporting procedures.

3. Inflation remains subdued, despite energy price increases associated with world oil market developments and the increase in energy taxes in April this year. 12-month CPI inflation was 0.7 percent in September, unchanged from August.

4. In financial markets, short- and long-term interest rates have both risen by more than 50 basis points since August, in response to evidence of strengthening activity in Germany and the euro area, as well as financial market developments in the United States. Threemonth rates are now 3.5 percent and ten-year bond yields 5.4 percent. Monetary conditions (including also the effects of recent exchange rate movements) have become somewhat less easy, returning toward early 1999 levels. 
This page intentionally left blank

CInternational Monetary Fund. Not for Redistribution 


\section{INTERNATIONAL MONETARY FUND}

EXTERNAL

Public Information Notice

RELATIONS

DEPARTMENT

Public Information Notice (PIN) No. 99/101

FOR IMMEDIATE RELEASE

November 3, 1999

International Monetary Fund

$70019^{\text {th }}$ Street, NW

Washington, D. C. 20431 USA

\section{IMF Concludes Article IV Consultation with Germany}

On October 20,1999, the Executive Board concluded the Article IV consultation with Germany. ${ }^{1}$

\section{Background}

By 1998, Germany's latest labor shakeout episode had been completed, and the economy appeared poised for a cyclical upswing. Instead, the upswing was waylaid by the emerging market crisis, which hit German exports particularly hard and stopped growth in its tracks in late 1998 , with GDP declining by 0.3 percent in the fourth quarter. The resulting knock to business confidence was exacerbated by uncertainty about the policy direction of the new government elected in late 1998, and economic activity remained sluggish in the first half of 1999.

The recent growth setback stifled the first signs in several years of rising employment. A high proportion of unemployment (some 9 percent on a standardized basis) is structural and concentrated among the low paid, having ratcheted up over time as a result of the interaction of German economic institutions-notably solidaristic wage bargaining and a generous safety net-with a sequence of economic shocks. Inflation has been subdued, with annual average CPI inflation below 2 percent since 1995 underpinned by subdued unit labor cost growth, deregulation measures, and a sharp decline in import prices driven by a decline in world prices of raw materials.

Monetary conditions have eased significantly since late 1998, reflecting both policy actions and exchange rate developments. Short-term interest rates were reduced by the Bundesbank to 3 percent in December 1998 and, in the new context of EMU, by the European Central Bank to $21 / 2$ percent in April 1999. The depreciation of the euro against other currencies since its

\footnotetext{
${ }^{1}$ Under Article IV of the IMF's Articles of Agreement, the IMF holds bilateral discussions with members, usually every year. A staff team visits the country, collects economic and financial information, and discusses with officials the country's economic developments and policies. On return to headquarters, the staff prepares a report, which forms the basis for discussion by the Executive Board. At the conclusion of the discussion, the Managing Director, as Chairman of the Board, summarizes the views of Executive Directors, and this summary is transmitted to the country's authorities. In this PIN, the main features of the Board's discussion are described.
} 
inception in January 1999 has also been supportive of activity. EMU has been associated with a large increase in cross-border capital flows, suggesting rapid financial integration within the euro area.

The general government deficit is projected at just under 2 percent of GDP in 1999, in line with budget estimates and the objectives of the January 1999 Stability Program. In June 1999 the authorities proposed a package of spending measures that would bring the fiscal deficit toward balance over the medium-term while making room for tax reforms that would lower the tax burden.

Short-term prospects are favorable. An improved external environment, easier monetary conditions, and greater clarity on policy should all support short-term recovery. The staff projects GDP growth to pick up from about 11/2 percent in 1999 to 21/2 percent in 2000.

\section{Executive Board Assessment}

Executive Directors observed that, after a rather disappointing year, Germany's short-term growth outlook was reasonably bright in view of the markedly improved external environment and the authorities' recent steps to clarify and strengthen fiscal policy. Most Directors cautioned, however, that Germany's long-standing structural weaknesses, in particular as regards labor market institutions, would need to be addressed to assure strong medium-term prospects.

Directors commended Germany's role in the successful launching of the euro and the Bundesbank's leadership in fostering a climate of low inflation in Europe. Directors noted that, in the new institutional context following the shift of monetary policy responsibility to the European Central Bank, monetary conditions were appropriately supportive of German activity and that external competitiveness was satisfactory.

Directors warmly welcomed the scale, pace, and composition of the government's fiscal program for 2000 and beyond. The package should not only ensure that the fiscal position stays in line with the Maastricht requirements, but also help regain room for fiscal maneuver and improve the conditions for private initiative and job creation. Directors endorsed, in particular, the emphasis on targeted cuts in current spending, noting that the focus on cuts in structurally significant areas lent credibility to the authorities' overall strategy of consolidation and tax reform. If firmly implemented, the fiscal program would bring the medium-term fiscal position close to balance, confirming Germany's commitment to fiscal consolidation and to the undertakings of the Stability and Growth Pact. Directors added that automatic fiscal stabilizers would need to play a more prominent role under European Monetary Union (EMU). In that connection, several Directors suggested that Germany allow the operation of automatic fiscal stabilizers if growth deviated from budget projections, particularly once the underlying fiscal situation had strengthened.

Directors also welcomed the authorities' tax reform proposals. They observed that cuts in Germany's high statutory business income tax rates, financed by base broadening, would increase the efficiency of the tax system. At the same time, Directors pointed to significant 
areas of unfinished business, notably as regards personal income taxation, where rates would remain high. Directors therefore encouraged the authorities to remain focused on expenditure restraint, which would make room for further lowering of the tax burden.

While thus welcoming the authorities' recent fiscal initiatives, as well as their implementation of a number of structural reforms, Directors cautioned that these policies were unlikely to prove sufficient to address Germany's deep-seated labor market problems and especially the task of absorbing the lower skilled into gainful employment. Moreover, a number of Directors considered that some of the government's initial labor market actions, for example, increased restrictions on "DM630 jobs," appeared to be in the wrong direction. Directors were concerned that, in the absence of decisive labor market reforms, Germany's medium-term macroeconomic prospects could again be undermined by labor shake-out, rising unemployment, and eventually renewed fiscal pressures.

Avoiding these pitfalls would, in the German context, necessarily require a cooperative approach, and Directors were encouraged that the authorities had initiated an "Alliance for Jobs" as a forum for reaching labor market solutions with the social partners. In this context, many Directors noted that several smaller European countries with like-minded distributional concerns had adopted policies that could offer useful benchmarks for reform, while recognizing that effective and workable solutions would need to take into account Germany's own circumstances and institutions. The key was to focus on encouraging employment through the establishment of appropriate incentives for all the economic agents in the labor market, with distributional objectives pursued through a well-targeted tax and transfer system, rather than through the workings of the labor market. Such an employment-oriented approach was preferable to efforts to reduce labor supply, for example, through the schemes to promote early retirement. Directors accordingly called for steps to reduce the cost of employing lower-skilled workers, both through greater flexibility in wage setting and nonwage work conditions, and lower social contributions for lower-skilled workers; to tighten eligibility requirements for social safety net benefits; to shift to a less comprehensive coverage of public social insurance through the development of a larger private insurance pillar, as foreshadowed by recent proposals; and to implement income safeguards in the form of in-work benefits for the lower-paid. While most Directors encouraged speedy and comprehensive action, some thought that a more gradual approach might be necessary, pointing to the time needed to change time-honored institutions and practices and to foster ownership by the social partners. Directors underscored that the fiscal costs of a labor market reform package would need to be consistent with medium-term fiscal consolidation targets.

Directors welcomed the recent steps toward deregulation in the product markets-notably in the energy and telecommunications sectors-but urged further action, including pruning the massive number of business regulations and liberalizing shop opening hours. Directors noted that Germany's financial markets had continued to undergo extensive changes in response to competitive pressures brought about by EMU and global financial trends. While Directors recognized that banks had increased their provisioning against risk and that a sizable share of the exposures to emerging market economies was covered by government guarantees, they nevertheless emphasized the need for continued supervisory vigilance. Several Directors 
suggested that the authorities publish more aggregate information on the nonperforming loans and risk exposures of the German banking system.

Directors noted that Germany's statistics, while generally adequate for surveillance, are in a period of transition following the welcome adoption of new European national accounting standards. In this connection, Directors took the view that the authorities should attempt to close transitional gaps related to the labor market and national accounts data as soon as possible.

Directors commended Germany for its prominent role in strengthening the Initiative for Heavily Indebted Poor Countries, as well as for its significant financial support for transition economies. However, they noted with regret that the level of official development assistance was projected to decline in coming years, and urged the authorities to reconsider their plans for such assistance.

Public Information Notices (PINs) are issued, (i) at the request of a member country, following the conclusion of the Article IV consultation for countries seeking to make known the views of the IMF to the public. This action is intended to strengthen IMF surveillance over the economic policies of member countries by increasing the transparency of the IMF's assessment of these policies; and (ii) following policy discussions in the Executive Board at the decision of the Board. As part of a pilot project, the staff report (use the free Adobe Acrobat Reader to view this pdf file) for the 1999 Article IV consultation with Germany is also available on the IMF's website (http://www.imf.org). 
Germany: Selected Economic Indicators

\begin{tabular}{|c|c|c|c|c|c|c|c|}
\hline & 1994 & 1995 & 1996 & 1997 & 1998 & $19991 /$ & $20001 /$ \\
\hline & \multicolumn{7}{|c|}{ Change in percent, unless otherwise noted } \\
\hline $\begin{array}{l}\text { Economic Activity and prices } \\
\text { Real GDP }\end{array}$ & 23 & 17 & 08 & 15 & 22 & 14 & \\
\hline Net exports 2/ & $\begin{array}{l}2.3 \\
0.1\end{array}$ & $\begin{array}{l}7.1 \\
0.1\end{array}$ & 0.5 & $\begin{array}{l}1.5 \\
0.8\end{array}$ & $\begin{array}{r}2,2 \\
-0.3\end{array}$ & $\begin{array}{r}1.4 \\
-0.6\end{array}$ & $\begin{array}{l}2.5 \\
0.4\end{array}$ \\
\hline Domestic demand & 2.2 & 1.7 & 0.3 & 0.7 & 2.5 & 2.0 & 2.2 \\
\hline Private consumption & 1.0 & 2.1 & 0.8 & 0.7 & 2.3 & 2.1 & 2.4 \\
\hline Gross fixed investment & 4.0 & -0.7 & -1.1 & 0.5 & 1.4 & 2.9 & 3.4 \\
\hline Construction investment & 6.9 & -1.8 & -2.9 & -1.4 & -3.9 & -1.6 & 1.1 \\
\hline Gross national saving (percent of GDP) & 22.1 & 21.9 & 21.3 & 21.5 & 21.7 & 22.2 & 22.9 \\
\hline Gross domestic investment (percent of GDP) & 23.2 & 22.7 & 21.6 & 21.6 & 21.8 & 22.3 & 22.6 \\
\hline Labor force $3 /$ & 0.2 & -0.5 & 0.0 & 0.3 & -0.2 & -0.4 & -0.2 \\
\hline Employment 3/ & -0.3 & -0.1 & -0.8 & -0.8 & 0.4 & 0.1 & 0.3 \\
\hline Standardized unemployment rate (in percent) & 8.3 & 8.1 & 8.8 & 9.8 & 9.4 & 8.9 & 8.5 \\
\hline Unit labor costs (whole economy) 4/ & 0.5 & 2.0 & 0.6 & -0.8 & -0.4 & $\ldots$ & \\
\hline GDP deflator & 2.5 & 2.0 & 1.0 & 0.8 & 1.0 & 1.0 & 1.2 \\
\hline \multirow[t]{2}{*}{ Harmonized CPI index } & $\ldots$ & $\ldots$ & 1.2 & 1.5 & 0.6 & 0.4 & 0.8 \\
\hline & \multirow{2}{*}{\multicolumn{7}{|c|}{ In percent of GDP }} \\
\hline Public finance & & & & & & & \\
\hline General government balance 5/ & -2.5 & -3.2 & -3.4 & -2.6 & -1.7 & -1.9 & -1.1 \\
\hline Structural government balance & -2.3 & -2.9 & -2.3 & -1.1 & -0.3 & -0.3 & 0.2 \\
\hline General government gross debt & 50.2 & 58.3 & 60.8 & 61.5 & 61.1 & 60.6 & 59.5 \\
\hline \multicolumn{8}{|l|}{ Money and credit } \\
\hline Domestic credit & 8.1 & 7.3 & 7.6 & 6.0 & 6.4 & $\ldots$ & $\ldots$ \\
\hline \multirow[t]{2}{*}{ M3 } & 3.6 & 2.7 & 7.9 & 4.6 & 5.9 & $\ldots$ & $\ldots$ \\
\hline & \multicolumn{7}{|c|}{ Percent } \\
\hline \multicolumn{8}{|l|}{ Interest rates } \\
\hline Three month money market rate 6 l & 5.3 & 4.5 & 3.3 & 3.3 & 3.5 & 2.7 & $\ldots$ \\
\hline \multirow{2}{*}{ Ten-year government bond yield $6 /$} & 6.9 & 6.9 & 6.2 & 5.7 & 4.6 & 5.1 & $\ldots$ \\
\hline & \multicolumn{7}{|c|}{ In billions of DM, unless otherwise noted } \\
\hline $\begin{array}{l}\text { Balance of payments } \\
\text { Exports } 71\end{array}$ & & & & 10313 & & & 12126 \\
\hline Imports 7I & 787.8 & 841.8 & $\begin{array}{l}911.4 \\
876.2\end{array}$ & 977.9 & $1,039.8$ & $1,076.2$ & $1,155.2$ \\
\hline Trade balance (percent of GDP) & 2.1 & 2.3 & 2.6 & 3.0 & 3.3 & 2.8 & 3.1 \\
\hline Current account balance & -36.5 & -27.2 & -8.4 & -2.4 & -7.4 & -3.8 & 8.3 \\
\hline \multirow[t]{2}{*}{ Current account (percent of GDP) } & -1.1 & -0.8 & -0.2 & -0.1 & -0.2 & -0.1 & 0.2 \\
\hline & \multirow{2}{*}{\multicolumn{7}{|c|}{ Period average }} \\
\hline Exchange rate & & & & & & & \\
\hline Deutsche mark per US dollar 6 / & 1.62 & 1.43 & 1.50 & 1.73 & 1.76 & 1.88 & ... \\
\hline Euro per US dollar $6 /$ & 0.83 & 0.76 & 0.79 & 0.88 & 0.89 & 0.96 & $\ldots$ \\
\hline Nominal effective rate $(1990=100) 8 /$ & 106.4 & 111.8 & 108.9 & 103.9 & 104.1 & 101.9 & $\ldots$ \\
\hline Real effective rate $(1990=100) 8 / 9 /$ & 111.6 & 119.5 & 117.0 & 108.7 & 105.7 & 101.3 & $\ldots$ \\
\hline
\end{tabular}

Sources: Deutsche Bundesbank; Statistisches Bundesamt, Volkswirtschaftliche Gesamtrechnungen; IMF, International Financial Statistics; IMF, World Economic Outlook; and staff projections.

1/ Staff projections, if not otherwise indicated.

2/ Contribution to GDP growth.

3/ Domestic definition on a national accounts basis; according to new integrated system of economic accounts (ESA95).

4/ National accounts definition.

5/ On a national accounts basis; according to new integrated system of economic accounts (ESA95).

6/ Data for 1999 refer to September 21, 1999.

$7 /$ Includes supplementary trade items.

8/ Data for 1999 refer to August 1999.

9/ Based on relative normalized unit labor cost in manufacturing. 